Boise State University

ScholarWorks

Community and Environmental Health Faculty Department of Community and Environmental Publications and Presentations

$3-2020$

\title{
Synthetic Pesticides and Health in Vulnerable Populations: Agricultural Workers
}

\author{
Cynthia L. Curl \\ Boise State University \\ Meredith Spivak \\ Boise State University \\ Rachel Phinney \\ Boise State University \\ Luke Montrose \\ Boise State University
}

This is a post-peer-review, pre-copyedit version of an article published in Synthetic Chemicals and Health. The final authenticated version is available online at doi: $10.1007 / s 40572-020-00266-5$ 
This is an author-produced, peer-reviewed version of this article. The final, definitive version of this document can be found online at Synthetic

Chemicals and Health, published by Springer. Copyright restrictions may apply. doi: 10.1007/s40572-020-00266-5

\title{
Synthetic Pesticides and Health in Vulnerable Populations: Agricultural Workers
}

\author{
Cynthia L. Curl, PhD \\ Department of Community and Environmental \\ Health \\ Boise State University \\ cynthiacurl@boisestate.edu \\ Rachel Phinney, BS \\ Department of Community and Environmental \\ Health \\ Boise State University
}

\author{
Meredith Spivak, MS \\ Department of Community and Environmental \\ Health \\ Boise State University \\ Luke Montrose, PhD \\ Department of Community and Environmental \\ Health \\ Boise State University
}

\begin{abstract}
Purpose of Review: This review aims to summarize epidemiological literature published between May 15, 2018 and May 14, 2019 that examines the relationship between exposure to synthetic pesticides and health of agricultural workers.

Recent Findings: Current research suggests that exposure to synthetic pesticides may be associated with adverse health outcomes. Agricultural workers represent a potentially vulnerable population, due to a combination of unique social and cultural risk factors as well as exposure to hazards inherent in farm work. Pesticide exposure among agricultural workers has been linked to certain cancers, DNA damage, oxidative stress, neurological disorders, as well as respiratory, metabolic, and thyroid effects.

Summary: This review describes literature suggesting that agricultural workers exposed to synthetic pesticides are at an increased risk of certain cancers and neurological disorders. Recent research on respiratory effects is sparse, and more research is warranted regarding DNA damage, oxidative stress, metabolic outcomes and thyroid effects.
\end{abstract}

Keywords: farmworkers, pesticide exposure, synthetic pesticides, agricultural workers, cancer, DNA damage

Acknowledgments: Research reported in this publication was supported by the National Institute of Environmental Health Sciences of the National Institutes of Health under Award Number K01ES028745. The content of this manuscript, including all findings and conclusions, is solely the responsibility of the authors and does not necessarily represent the official views of the National Institutes of Health.

\section{Introduction}

There are over 1 billion agricultural workers in the world[1]. In the US alone, there are more than 3 million seasonal and migrant workers, self-employed farmers, family members working on family farms, hired workers and contract laborers[2, 3]. In South Asia and Sub-Saharan Africa, more than half of all employment is in agriculture[1]. In many countries, including the US, farm working populations are becoming increasingly older and are comprised of a growing number of women[2]. Agricultural workers are among the most vulnerable working populations due to social and cultural risk factors frequently associated with their ethnicity, immigration status, social class and rural location, as well as disparities related to language barriers and lack of access to healthcare[4-7]. In addition, these potential risk factors can be exacerbated by occupational hazards associated with agricultural work, including exposure to environmental hazards such as synthetic pesticides and fertilizers, diesel exhaust, ultraviolet radiation, biologically active dusts, and zoonotic viruses and bacteria, all of which may put farm working populations at an increased risk for a variety of adverse health effects[ $[8,9]$. 
This is an author-produced, peer-reviewed version of this article. The final, definitive version of this document can be found online at Synthetic Chemicals and Health, published by Springer. Copyright restrictions may apply. doi: 10.1007/s40572-020-00266-5

This review summarizes recent epidemiological literature regarding potential health effects (specifically cancer, DNA damage and oxidative stress, neurological disorders, and respiratory, metabolic, and thyroid effects) of occupational exposure to synthetic pesticides among agricultural workers. In this review, we include descriptive, cross-sectional, cohort and case-control studies published over the past year, between May 15, 2018 and May 14, 2019. This relatively brief timeframe for review was selected for several reasons. First, this review considers exposures to all classes of agricultural pesticides and numerous diverse adverse health outcomes, creating a broad reach. Second, this year has seen the publication of several studies that include large agricultural cohorts and/or pooled analyses across multiple cohorts. Third, there has been a marked increase in the number of studies investigating exposures and health effects in previously understudied populations (e.g., Latin America and Asia) and employing emerging technologies (e.g., studies evaluating potential DNA damage). By focusing on just the last year, we are able to contribute a novel evaluation to the existing literature.

We define agricultural workers to include farmers, farm owners, farm workers, field workers, growers, harvesters, packers, graders and sorters, as well as agricultural pesticide handlers (mixers, loaders, cleaners and sprayers). This review did not consider take-home exposure among families of agricultural workers or spray drift in agricultural communities, nor did we include studies evaluating health effects exclusively among livestock workers, florists, pesticide manufacturers or commercial pesticide users. We also did not include animal toxicology studies, metaanalyses that do not represent novel investigations of pooled primary data, case reports, or acute poisonings.

Literature searches were conducted in PubMed, Google Scholar, and the Boise State University Alberton's Library System using a predetermined list of search words and fragments related to agriculture work, pesticide exposure and health outcomes. These searches resulted in a total of 508 articles, of which 484 were excluded due to inappropriate scope or focus on non-farm working populations. The results of the remaining 24 studies represent primary literature, are grouped according to health outcome and are discussed in the following sections.

\section{Cancer}

Several studies have identified that farmers have lower rates of mortality than the general population and lower rates of specific cancers, including those of the lung, esophagus, bladder, liver and colon, primarily attributed to low rates of smoking and high rates of physical activity in this population[9-11]. At the same time, farmers and other agricultural workers have demonstrated elevated rates of other types of cancer, including that of the prostate, brain, and lip, as well as melanoma and skin cancers, and lymphohematopoietic malignancies[8, 9, 12-17]. In this review, we identified six studies published in the last year that add to our existing understanding of the relationship between agricultural work and cancer.

The Agricultural Health Study (AHS) provides some of the most compelling insights into the relationship between agricultural work, pesticide exposures and cancer. This large prospective study was initiated in North Carolina and Iowa in 1993 with the express intention of identifying and quantifying cancer risks, and other non-cancer health outcomes, among a cohort of nearly 90,000 individuals including licensed private pesticide applicators (mostly farmers), their spouses, and commercial pesticide applicators[18]. The most recent evidence on overall cancer incidence in the AHS was published in April of 2019. Lerro et al. present age, year, sex, and race-adjusted standardized incidence ratios (SIRs) for cancer sites in the AHS relative to the general population for an extended period of followup, representing 20 years and 12,420 incident cancers[19] (Table 1). They found that while overall cancer incidence was indeed lower than in the general population - driven mainly by lower incidences of smoking, alcohol, or obesityrelated cancers such as those of the respiratory, bladder and digestive systems - private pesticide applicators (primarily farmers) had higher incidence rates of lip and prostate cancer, B-cell lymphomas, chronic lymphocytic leukemia, acute myeloid leukemia, thyroid cancer, and testicular cancer. The authors speculated that the increases in lip cancer may be due to UV exposure and that the excess of thyroid and testicular cancer may be due to pesticide exposure in this population.

Other analyses among large cohort studies also provide insights into the relationship between agricultural work and cancer. In March of 2019, the Consortium of Agricultural Cohort Studies (AGRICOH) published a pooled analysis of the relationship between pesticide use and non-Hodgkin lymphoid malignancies (NHL) among participants in three agricultural cohorts[20] (Table 1). These cohorts included the AGRIculture and CANcer (AGRICAN) study, which enrolled over 180,000 individuals in France between 2005 and 2007 who were part of the national health insurance system of agricultural workers[21]; the Cancer in the Norwegian Agricultural Population (CNAP) study, from which this pooled analysis included nearly 150,000 farm owners and workers[22]; and the AHS study, described above. This 
investigation included 2,430 cases of NHL among 316,270 farmers, and the researchers found almost no association between exposure to 4 pesticide chemical groups and 33 pesticide active ingredients with NHL overall or with any NHL subtype. However, the authors noted that associations may vary by cancer subtype and by pesticide, and they did observe weak to moderate positive associations between ever use of terbufos and NHL overall; ever use of deltamethrin and chronic lymphocytic leukemia/small lympocytic lymphoma; and ever use of glyphosate and diffuse large B-cell lymphoma.

Andreotti et al. (2018) specifically examined the relationship between use of the common herbicide, glyphosate, and cancer incidence in the AHS and found no relationship between glyphosate and cancer at any site, with the exception of an elevated but non-significant association between applicators in the highest exposure quartile (compared with never users) and acute myeloid leukemia[23] (Table 1). This analysis included 5,779 incident cancer cases among 54,521 licensed pesticide applicators. This finding differs somewhat from that observed in the AGRICOH analysis described above, of which the AHS was a part, where glyphosate exposure was associated with diffuse large B-cell lymphoma. It may be worth noting that the analysis described by Andreotti et al. was limited by incomplete followup; 20,968 participants (37\% of the cohort) did not complete the follow-up questionnaire, and it has been suggested that the method by which the researchers imputed the missing data may have biased the results towards the null[24].

In another chemical-specific study within the AHS cohort published in the past year, Lerro et al. (2018) investigated the relationship between use of another common herbicide, alachlor, and cancer incidence[25] (Table 1). This analysis included 48,685 licensed pesticide applicators, among whom 51.6\% reported use of alachlor. Although the researchers in this study also were limited by incomplete follow-up data, they observed a strong positive association and exposureresponse trend between alachlor use and laryngeal cancer. They also observed an elevated, but non-significant, relationship between alachlor use and myeloid leukemia among the most highly exposed participants. No significant associations were observed between exposure to alachlor and lymphohematopoietic cancers overall nor specifically with NHL.

While multiple studies have shown that farmers are at relatively low risk of lung cancer[10, 12, 16, 26], a recent analysis in the AGRICAN cohort found trends suggesting that winegrowers may be at a slightly higher risk of adenocarcinoma compared to non-winegrowing farmers, possibly attributable to the historic use of arsenical pesticides in vineyards[27] (Table 1). This same study also found pea growers, harvesters, and pesticide applicators to be at increased risk of small cell lung cancer, though there was a low number of exposed cases and the results were not statistically significant. In contrast, these researchers observed a negative association between lung cancer and production of corn and wheat/barley, which is more consistent with previous studies of the relationship between farming and lung cancer. Also in the AGRICAN cohort, Piel et al. (2018) described a positive association between central nervous system (CNS) tumors, particularly gliomas and meningiomas, and use of carbamate insecticides[28] (Table 1). Confidence in these results are strengthened by the consistency in findings across multiple individual carbamates.

In summary, most studies published in the past year consistently show that agricultural workers are at increased risk of some cancers, but the risk varies by cancer subtype and pesticide exposure. These studies, and particularly the study including 20 years of follow-up in the AHS[19], confirmed previous evidence that the incidence of some cancers is lower among agricultural workers compared to the general population. However, it is possible that individuals whose health status may have rendered them unable to work may be underrepresented in agricultural cohorts, suggesting that the healthy worker effect could potentially be a factor to consider when interpreting these results.

Other cancers such as prostate, lip and certain lymphomas, as well as acute myeloid leukemia, are higher among those working in agriculture compared to the general population, which may reflect differences in lifestyle and behavior, as well as potential exposures to agricultural chemicals. In terms of effects of individual pesticides or classes of pesticides, some of the most compelling relationships were between exposure to alachlor and laryngeal cancer within the AHS study[25] and exposure to carbamates and gliomas and meningiomas within the AGRICAN study[28]. Evidence was inconsistent regarding the relationship between glyphosate and cancer. One study found a slight increase in diffuse large B-cell lymphoma among those exposed to glyphosate[20] - which supports the results of a recent meta-analysis of six studies that found an overall increased risk of NHL among individuals in the highest exposure groups[29] - while another showed no such association[23]. 
This is an author-produced, peer-reviewed version of this article. The final, definitive version of this document can be found online at Synthetic Chemicals and Health, published by Springer. Copyright restrictions may apply. doi: 10.1007/s40572-020-00266-5

\section{DNA Damage and Oxidative Stress}

Exposure to cytotoxic and genotoxic substances can result in chromosomal aberrations and DNA damage, which may be early precursors for the onset of clinical health effects, particularly cancer[30, 31]. We reviewed eight publications from the past year that investigated potential chromosomal aberrations and DNA damage related to pesticide exposure among agricultural workers. While there is no single standardized test for chromosomal aberrations and DNA damage, and measurements involve a range of molecular biomarkers and endpoints, the most widely used and accepted procedures are comet and micronucleus assays[32, 33]. Comet assays, which provide measurements such as comet tail length, shape, and/or intensity (known as comet tail moment), can detect various types of DNA damage including single and double DNA strand breaks. A longer tail, increased moment, or increased percent DNA in the tail are considered indicators of DNA damage[32, 34, 35]. Micronucleus assays measure the presence of micronuclei, as well as the presence of DNA damage biomarkers such as nuclear buds. Micronuclei are whole chromosomes or damaged chromosome fragments that are not incorporated into the daughter nuclei during mitosis and are thus can be used as an indication of chromosomal abnormalities[33, 36] The majority, but not all, of the studies in this section report an increase in chromosomal aberrations and DNA damage among agricultural workers exposed to pesticides compared to control populations [37-42] (Table 2).

Hutter et al. (2018) compared buccal cells from 38 pesticide applicators who were exposed to a complex mixture of pesticides and 33 organic farmers, presumably unexposed to pesticides, in the Jarabacoa coffee production region in the Dominican Republic. After adjusting for age, body mass index, smoking, tobacco chewing, alcohol consumption, dental x-rays in the past month, and frequency of eating spicy foods, these researchers concluded that pesticide applicators had significantly increased odds for all micronucleus assay endpoints evaluated, including the following: total number of micronuclei cells, total number of micronuclei, nuclear buds, broken eggs, and binucleated cells[37]. Of note, fewer than $14 \%$ of pesticide applicators in this study reported wearing personal protective equipment (PPE) while spraying. This is consistent with previous studies that report chromosomal damage among agricultural workers who predominately did not use PPE[43, 44]. Further, a similar study among agricultural workers who did utilize PPE showed the converse -- no significant increases in genotoxic outcomes were observed[45].

Results comparable to Hutter et al. were observed by Kahl and colleagues[38], who enrolled 121 tobacco field workers exposed to nicotine and complex pesticide mixtures and 121 non-exposed individuals working in offices and retail in Brazil, matched by sex and age, and excluding participants who were smokers or had chronic health conditions. Comet assay on whole blood cells showed that agricultural workers had significantly increased DNA damage based on tail size and shape, and micronucleus assay on buccal cells showed significantly increased mean levels of micronuclei, nuclear buds, and binucleated cells.

A 2019 study in Punjab, Pakistan found significantly increased comet tail length and comet frequency measured using whole blood DNA from pesticide industry workers and pesticide sprayers compared to controls, matched by age, location, and smoking status[39]. Similarly, researchers in Egypt found that several comet assay parameters including tail length, percent DNA in tail, and tail moment in whole blood DNA were significantly elevated among rural pesticide sprayers and urban researchers using pesticides in laboratories (exposed mostly to the insecticides malathion, chlorpyrifos, dimethoate, and carbofuran), compared to researchers and rural controls not occupationally exposed to pesticides[40]. While this study did match on age and smoking status, it did not adjust for sex or consider the use of PPE. A cross-sectional study conducted in tea gardens in India found that women who plucked tea leaves (considered occupationally exposed to pesticides, $\mathrm{n}=77$ ), had significantly increased mean comet tail length, percent DNA in tail, and tail moment in peripheral lymphocyte DNA compared to women with no occupational exposure to pesticides $(\mathrm{n}=66)$. Important for the interpretation of this data, almost $80 \%$ of exposed women reported not using PPE and information regarding quantity and frequency of pesticide mixture application at the tea garden was unknown[41].

Finally, a case-control study by Intranuovo et al. (2018) in Italian farming regions compared 2,374 comet assay images from peripheral lymphocytes from 22 agricultural workers involved in the production of vegetables, grapes, and olive trees (with exposure mainly to chlorpyrifos, deltamethrin, glyphosate, dimethoate, mancozeb, and fosetyl) and 24 nonexposed individuals. These researchers observed significantly increased odds of tail moment and tail length measurements above the $75^{\text {th }}$ percentile among those occupationally exposed to pesticides, after adjusting for age and smoking status. Of note, all exposed agricultural workers in this study reported using PPE (masks, gloves, and suits)[42]. 
This is an author-produced, peer-reviewed version of this article. The final, definitive version of this document can be found online at Synthetic Chemicals and Health, published by Springer. Copyright restrictions may apply. doi: 10.1007/s40572-020-00266-5

However, not all studies we reviewed were consistent[46, 47] (Table 2). Cattelan et al. (2018) compared whole blood DNA damage between farmers in Brazil who reported occupational use of various pesticide combinations and farmers who did not report occupational pesticide use, and found no significant differences in micronucleus frequency[46]. In this study, over $60 \%$ of farmers reported using some form of PPE, though exact pesticide combinations and frequency of pesticide use could not be determined due to different agrochemical requirements for various crops. Likewise, Sapbamrer et al. (2019) compared pre- and post-application season exposures among 56 farmers in Thailand and also found no statistically significant differences in tail length or tail moment in comet assay of peripheral lymphocyte samples[47]. Of note, this is the only study in this review section that examined DNA damage intra-individually and not between individuals.

Despite some inconsistencies, six of the eight epidemiological studies published in the past year examining genotoxic effects of pesticides identified increases in DNA damage among occupationally exposed agricultural workers compared to unexposed populations. While all of these studies utilized widely accepted assays for chromosomal aberrations and DNA damage, assessment of causality remains difficult for numerous reasons. Age, tobacco smoke, gender, diet, physical activity, and exposure to ultraviolet radiation have been shown to effect comet assay results[42], but not all studies in this review adjusted for these potential confounders. Differences in accounting for PPE use, doses, types, combinations, duration, and frequency of pesticide use among studies make it difficult to generalize results to all agricultural occupations. In addition, the comet assay in particular does not inclusively detect all types of cell damage nor is this assay on its own considered predictive of cancer risk[42]. Micronucleus assays are also limited by scorer bias, variability, and fatigue[48]. Finally, while it is outside the scope of this review to discuss the appropriateness of cell type selection, it must be noted that studies listed here were not consistent in their selection, ranging from buccal cells to whole blood to separated peripheral lymphocytes. This is problematic given that DNA repair capacity can vary by cell type[49]. Moreover, studies have identified that peripheral lymphocytes relative to whole blood may be more resilient to DNA damage[50], and this could impact the interpretability of the results reviewed here.

Four studies published in the past year - including three that also investigated DNA damage - evaluated the relationship between occupational pesticide exposure and markers of oxidative stress [38, 46, 47, 51] (Table 2). Oxidative stress results from an imbalance between free radicals/reactive oxygen species (ROS), and antioxidant species. When this imbalance favors ROS over antioxidants, oxidative damage may occur, resulting in cellular adaption, damage to cellular lipids, DNA, proteins, and carbohydrates, and/or cellular death[52, 53]. Studies have shown that oxidative damage may contribute to the development of a range of chronic conditions, including Alzheimer's disease and other neurodegenerative disorders, cancers, and diabetes[52, 54-57].

There are many cellular and molecular targets of ROS, and as such, measurements of oxidative stress and damage in humans are complex. Biological markers of oxidative stress can be non-specific to a single oxidative pathway, and methods and markers are often not standardized across studies, making comparisons difficult[52, 53]. Most studies measure the presence of biomarkers formed from reactions between ROS and other biological molecules and/or the disruption in antioxidative enzymatic activities[52, 53, 58]. Examples of oxidative stress biomarkers include thiobarbituric acid reactive substances (TBARS), 8-hydroxy-2'-deoxyguanosine (8-Oxo-dG), and total equivalent antioxidant capacity (TEAC). Examples of antioxidant enzymes include superoxide dismutase (SOD), glutathione peroxidase (GPx), catalase (CAT), and paraoxonase-1 (PON1).

Regarding oxidative stress biomarkers, Cattelan et al. (2018) found that farmers who used pesticides had significantly lower levels of TBARS, suggesting less oxidative stress, compared to farmers who did not use pesticides [46]. Sapbamrer et al.(2019) found no difference in 8-Oxo-dG among pesticide applicators pre- and post- pesticide application seasons[47]. In contrast, both Kahl et al. (2018) and Lozano-Panigua et al. (2018) found agricultural workers occupationally exposed to pesticides had significantly increased levels of oxidative stress biomarkers, including increased TBARS and TEAC[38], and ferric reducing ability of serum (FRAS) and total thiol groups (SHT) [51]. These inconsistent results make it difficult to draw conclusions about the relationship between agricultural work and biomarkers of oxidative stress.

Regarding antioxidant enzyme activity, Cattelan et al. (2018) observed that farmers who used pesticides had significantly reduced levels of SOD, GPx, and glutathione reductase (GSH) compared to farmers who did not use pesticides[46]. The authors note that this effect may represent a reduced antioxidant defense system in response to an increase in ROS. Other recent studies suggest occupational pesticide exposure is associated with elevations, rather than reductions, in antioxidant enzyme activity. Sapbamrer and colleagues found significantly increased SOD activity 
This is an author-produced, peer-reviewed version of this article. The final, definitive version of this document can be found online at Synthetic Chemicals and Health, published by Springer. Copyright restrictions may apply. doi: 10.1007/s40572-020-00266-5

post-pesticide application season compared to pre-pesticide application season[47]. In addition, Lozano-Paniagua et al. (2018) found an elevated but non-significant increase in PON1 activity in greenhouse workers compared to controls[51]. This increase in antioxidant enzymatic activity may represent an adaptive response to an increase in the generation of free radicals[47].

The inconsistencies seen among these studies could be due to different doses, types, combinations, and duration of pesticides use, limitations inherent in cross-sectional study designs, and the difficulty in making meaningful measurements of oxidative stress. The latter point likely being exacerbated by nonuniform biological sample collection, storage, and assessment protocols between studies. It is worth noting that many of these studies were unable to determine exposure to specific pesticides and instead analyzed exposure to various complex pesticide mixtures used on a variety of crops. In addition, agricultural pesticide bans vary by country, and most of these studies were conducted in different countries with different types and levels of pesticide usage. While the papers included in this review observed conflicting results regarding oxidative stress biomarkers, most studies agreed that pesticide exposure may lead to disruptions in antioxidant enzyme homeostasis, though the direction of this disruption and possible underlying biological mechanisms are unclear and warrant further investigation.

\section{$\underline{\text { Neurologic Disorders }}$}

Numerous studies have documented neurologic effects of pesticide exposure. These effects include disruption of cholinergic function as well as various neurological disorders including Parkinson's disease, Alzheimer's disease, attention deficit hyperactivity disorder (ADHD), affective disorders, anxiety, depression, lower intelligence quotient, and delayed mental development[59-65]. These studies have primarily focused on organophosphate (OP) insecticides, although such effects have also been noted in conjunction with exposure to other pesticides as well.

This review describes four studies published in the past year regarding the relationship between occupational exposure to agricultural pesticides and neurological effects. A recent longitudinal study evaluated the frequency of ADHD symptoms in relation to biomarkers of exposure to chlorpyrifos, a common OP insecticide, among adolescents in Egypt[66] (Table 2). In this study, researchers measured urinary levels of tricholoro-2-pyridinol (TCPy - a metabolic product of chlorpyrifos exposure) and blood levels of acetylcholinesterase and butyrylcholinesterase (AChE and $\mathrm{BChE}$ - which indicate cholinergic response to OP exposure) among 59 participants who either did or did not work as pesticide applicators. The researchers found that those adolescents who worked as pesticide applicators were significantly more likely to demonstrate ADHD symptoms than non-applicators. They also observed a dose-response relationship between increasing levels of all three exposure biomarkers (TCPy, AChE, and BChE) and ADHD symptoms. Despite the small sample size, this study provides compelling evidence of a relationship between chlorpyrifos exposure and ADHD among adolescent pesticide applicators.

AChE inhibition was also measured as a marker of cholinergic disruption among a cohort of agricultural workers in the Trang Province of Thailand[67] (Table 2). Guytingco et al. (2018) conducted a cross-sectional study in which they surveyed 6,118 agricultural workers regarding pesticide-related symptoms. Blood samples were collected from 3,431 of these workers and analyzed for AChE. Low AChE levels were measured in 12.5\% of the cohort, most commonly among those who reported spraying and mixing pesticides. Individuals with low AChE were significantly more likely to report experiencing neurological symptoms associated with pesticide exposure, such as dizziness and headaches.

Exposure to pesticides and agricultural work has also been linked to anxiety, depression and suicide, although epidemiological studies on this are limited[68-71]. Serrano-Medina et al. (2019) conducted a cross-sectional study of AChE inhibition and neuropsychiatric disorders among agricultural workers in a rural village of Mexico[72] (Table 2 ). They found that agricultural workers $(n=140)$ had significantly more psychiatric disorders than control participants recruited from an urban area $(\mathrm{n}=100)$, including more frequent depression, major depression with suicidal risk, and depression-generalized anxiety. They also found a significant relationship between AChE inhibition and suicide risk.

Finally, in the AHS cohort, researchers investigated the association between high pesticide exposure events (HPEE), as a surrogate for acute, high-dose exposures, and olfactory impairment[73] (Table 2). This relationship was of interest because pesticides may affect the sense of smell by affecting peripheral olfactory structures and/or the central nervous system, and olfactory impairment has been recognized as one of the earliest symptoms of neurological disorders like Parkinson's disease and Alzheimer's disease[74, 75]. These researchers found that a history of self-reported HPEEs was significantly associated with olfactory impairment measured two decades later. 
This is an author-produced, peer-reviewed version of this article. The final, definitive version of this document can be found online at Synthetic Chemicals and Health, published by Springer. Copyright restrictions may apply. doi: 10.1007/s40572-020-00266-5

Overall, recent research is consistent regarding the relationship between pesticide exposure and neurological effects in agricultural workers. It is worth noting that all four of the relevant studies identified in the past year were focused on relatively high pesticide exposures, either self-identified as such, or sufficient to result in cholinergic inhibition. Together, these studies suggest that occupational exposure to synthetic pesticides - particularly OPs - is associated with neurological effects including dizziness and fatigue, ADHD, neuropsychiatric disorders, and olfactory impairment, a potential early predictor of neurodegeneration.

\section{$\underline{\text { Respiratory Effects }}$}

In addition to dermal absorption and ingestion, inhalation is an another pathway by which agricultural workers may be exposed to synthetic pesticides[76]. Such exposures are hypothesized to cause or exacerbate adverse respiratory symptoms in these workers[77, 78]. One publication in the past year investigated the relationship between occupational exposure to synthetic pesticides among agricultural workers and respiratory symptoms (Table 2). In this study, Buralli et al. (2018) investigated the prevalence of respiratory impairment in a cohort of family farmers $(\mathrm{n}=82)$ who had been exposed to multiple pesticides from an early age[79]. The prevalence of cough, nasal allergies, hay fever, breathlessness, and chest tightness were reported more frequently during the season in which the farmers were actively working in agriculture compared to the off-season. However, due to the small sample size, the confidence intervals around these estimates were wide and rarely reached statistical significance. The authors did report significant associations between lung function, as assessed by various spirometry variables, and self-reported pesticide exposure. Though limited by a lack of an unexposed control group, the results of this study are suggestive of a relationship between pesticide exposure and respiratory symptoms and pulmonary function impairment.

\section{Metabolic Effects}

Previous research has suggested that pesticide exposure, particularly exposure to organochlorine insecticides and some OPs, may be associated with type II diabetes mellitus[80-82]. Two epidemiologic studies published in the past year add to our knowledge of the relationship between occupational exposure to pesticides and metabolic diseases including diabetes.

One cross-sectional study analyzing data from participants of the Korea Farmers Cohort study found that the prevalence of diabetes was significantly higher in study participants who had ever been a farmer or had ever used any pesticides, compared to those who had not[83] (Table 2). Further, the odds of diabetes were significantly elevated with ever use of pesticides, years of pesticide use, frequency of pesticide use, volume/intensity of use, and cumulative exposure index of pesticide use, and this remained true among the overweight and obese groups when stratified by body mass index (BMI).

Another study among farmers in Thailand investigated differences in levels of adverse metabolic biomarkers between organic and conventional farmers[84] (Table 2). In this study, the authors investigated the role of pesticide use in metabolic pathways by considering employment as a conventional farmer to be a proxy for pesticide exposure, while organic farmers were considered unexposed. These researchers found significantly higher BMI, waist circumference, percent body fat, triglycerides, total cholesterol, and low-density lipoproteins among conventional farmers, compared to organic farmers. No significant differences were seen between type of farm work and blood glucose, blood pressure, or metabolic syndrome. While the researchers collected and controlled for multiple confounding variables, including alcohol intake, smoking, exercise, diet, stress and socioeconomics, there were significant differences in demographics and behavior between the organic and conventional farmers, and the authors acknowledge that their study results may still reflect uncontrolled confounding. Between this possibility and the cross-sectional study design, it is difficult to make a causal argument based on the results of this study.

Overall, research over the past year contributes to the weight of evidence suggesting a relationship between occupational exposure to synthetic pesticides and metabolic effects among agricultural workers. However, research in this area remains sparse and additional work will be required to confirm this relationship.

\section{Thyroid Effects}

There is some increasing evidence, though from a limited number of studies, to suggest that pesticide exposure may affect thyroid function[85]. Three initial studies in the AHS suggested a relationship between pesticide exposure and thyroid dysfunction[86-88]. Most recently, Shrestha et al. (2018) followed up on this work by analyzing data from 
This is an author-produced, peer-reviewed version of this article. The final, definitive version of this document can be found online at Synthetic Chemicals and Health, published by Springer. Copyright restrictions may apply. doi: 10.1007/s40572-020-00266-5

35,150 pesticide applicators in this cohort, among whom 829 had self-reported hypothyroidism[89] (Table 2). The researchers observed an increased risk of hypothyroidism with ever use of several specific pesticides, including chlordane, diazinon, dichlorvos, malathion, dicamba, glyphosate, and 2,4-D. However, results from this study are limited, as self-reported hypothyroidism may have low validity and diagnoses pulled from medical records are considered a more reliable measurement[90]. In a much smaller study, Bernieri et al. (2019) observed significant decreases in serum levels of thyroid stimulating hormone (TSH) and significant increases in free thyroxin (FT4) and total triiodothyronine (TT3) among 46 Brazilian soybean growers compared to 27 unexposed participants from urban regions[91] (Table 2).

These two studies add to the limited existing epidemiological literature suggesting that occupational exposure to synthetic agricultural pesticides may affect thyroid function. It is important to note that there is a variable course to thyroid disease, where hypothyroidism can develop after hyperthyroidism[92]. There are also many hormones, antibodies, and proteins involved in thyroid homeostasis, and pesticides have the potential to alter thyroid function via several mechanisms[89]. The specific types of pesticides, thyroid targets, and mechanisms that might underlie this relationship are complex, and as such additional toxicological and epidemiologic studies are warranted to further evaluate this relationship.

\section{Conclusions}

This review summarized epidemiological literature published between May 15, 2018 and May 14, 2019 examining the relationship between occupational exposure to agricultural pesticides and health outcomes including cancer, DNA damage and oxidative stress, neurological disorders, and respiratory, metabolic, and thyroid effects. Most studies published in the past year confirm that, while agricultural workers occupationally exposed to pesticides have a decreased incidence of some cancers, they are at an increased risk for others, such as prostate, lip and certain lymphomas, as well as acute myeloid leukemia, but the risk varies by cancer subtype and the specific pesticides. Studies also confirm that occupational exposure to synthetic pesticides - particularly organophosphates - is associated with neurological and neuropsychiatric effects and disorders. Results regarding respiratory function are limited but do suggest a relationship between agricultural pesticide exposure and adverse pulmonary function. Studies of DNA damage, oxidative stress, metabolic effects and thyroid effects suggest pesticide exposure among agricultural workers may be deleterious, but additional research in these areas is warranted.

Overall, agricultural workers may be at risk for various adverse outcomes due to synthetic pesticide exposure. However, further research is warranted to better inform causality, as there are many factors to consider when evaluating occupational pesticide exposure. Studies on pesticide exposure are often limited by their cross-sectional design, and consideration of the use of PPE and adjusting for the appropriate confounders is necessary. In addition, exposure to pesticides can occur via various routes (i.e. inhalation, dermal), is often not limited to one single pesticide, and may depend on frequency of application, creating difficulties in exposure assessment and the interpretation of results. Given the difficulty of controlling for confounding and establishing causality, animal studies, in addition to human studies, could help elucidate the relationship between exposure to pesticides and health outcomes. Worldwide pesticide consumption remains highest in South Asia and Latin America, and there has been a marked increase in the number of studies investigating occupational pesticide exposures and health effects in these previously understudied populations. While generalizations between studies is difficult due to geographic differences and agrochemical practices that vary between crops and countries this work indicates the importance of continued focus on the health of this vulnerable population. 
This is an author-produced, peer-reviewed version of this article. The final, definitive version of this document can be found online at Synthetic Chemicals and Health, published by Springer. Copyright restrictions may apply. doi: 10.1007/s40572-020-00266-5

\section{References}

1. Food and Agricultural Organization of the United Nations (FAO). FAO Statistical Yearbook. 2012. https://issuu.com/faosyb/docs/fao_statistical_yearbook_2012_issuu/24_Accessed 7/23/2019.

2. United States Department of Agriculture. Farm Labor. https://www.ers.usda.gov/topics/farm-economy/farmlabor/\#size. Accessed 7/15/2019.

3. National Center for Farmworker Health Inc. Farmworker Health Factsheet. Demographics. 2012. http://www.ncfh.org/uploads/3/8/6/8/38685499/fs-migrant_demographics.pdf.

4. Durden TE, Hummer RA. Access to Healthcare Among Working-Aged Hispanic Adults in the United States. Social Science Quarterly. 2006;87(5):1319-43. doi:10.1111/j.1540-6237.2006.00430.x.

5. Moyce SC, Schenker M. Migrant Workers and Their Occupational Health and Safety. Annual review of public health. 2018;39:351-65. doi:10.1146/annurev-publhealth-040617-013714.

6. Casey MM, Thiede Call K, Klingner JM. Are rural residents less likely to obtain recommended preventive healthcare services? American journal of preventive medicine. 2001;21(3):182-8.

7. Hu R, Shi L, Lee D, Haile GP. Access to and Disparities in Care among Migrant and Seasonal Farm Workers (MSFWs) at U.S. Health Centers. Journal of Health Care for the Poor and Underserved. 2016;27(3):14841502. doi:10.1353/hpu.2016.0107.

8. Blair A, Freeman LB. Epidemiologic studies in agricultural populations: observations and future directions. J Agromedicine. 2009;14(2):125-31. doi:10.1080/10599240902779436.

9. Blair A, Zahm SH. Agricultural exposures and cancer. Environ Health Perspect. 1995;103 Suppl 8:205-8. doi:10.1289/ehp.95103s8205.

10. Blair A, Zahm SH, Pearce NE, Heineman EF, Fraumeni JF, Jr. Clues to cancer etiology from studies of farmers. Scandinavian journal of work, environment \& health. 1992;18(4):209-15.

11. Davis DL, Blair A, Hoel DG. Agricultural exposures and cancer trends in developed countries. Environ Health Perspect. 1993;100:39-44. doi:10.1289/ehp.9310039.

12. Koutros S, Alavanja MC, Lubin JH, Sandler DP, Hoppin JA, Lynch CF et al. An update of cancer incidence in the Agricultural Health Study. J Occup Environ Med. 2010;52(11):1098-105. doi:10.1097/JOM.0b013e3181f72b7c.

13. Merhi M, Raynal H, Cahuzac E, Vinson F, Cravedi JP, Gamet-Payrastre L. Occupational exposure to pesticides and risk of hematopoietic cancers: meta-analysis of case-control studies. Cancer causes \& control : CCC. 2007;18(10):1209-26. doi:10.1007/s10552-007-9061-1.

14. Eriksson M, Hardell L, Carlberg M, Akerman M. Pesticide exposure as risk factor for non-Hodgkin lymphoma including histopathological subgroup analysis. International journal of cancer. 2008;123(7):1657-63. doi:10.1002/ijc.23589.

15. Nordby KC, Andersen A, Kristensen P. Incidence of lip cancer in the male Norwegian agricultural population. Cancer causes \& control : CCC. 2004;15(6):619-26. doi:10.1023/B:CACO.0000036169.90864.e2.

16. Lemarchand C, Tual S, Leveque-Morlais N, Perrier S, Belot A, Velten M et al. Cancer incidence in the AGRICAN cohort study (2005-2011). Cancer epidemiology. 2017;49:175-85. doi:10.1016/j.canep.2017.06.003.

17. Koutros S, Beane Freeman LE, Lubin JH, Heltshe SL, Andreotti G, Barry KH et al. Risk of total and aggressive prostate cancer and pesticide use in the Agricultural Health Study. Am J Epidemiol. 2013;177(1):59-74. doi:10.1093/aje/kws225.

18. Alavanja MC, Sandler DP, McMaster SB, Zahm SH, McDonnell CJ, Lynch CF et al. The Agricultural Health Study. Environmental health perspectives. 1996;104(4):362-9. doi:10.1289/ehp.96104362.

19. Lerro CC, Koutros S, Andreotti G, Sandler DP, Lynch CF, Louis LM et al. Cancer incidence in the Agricultural Health Study after 20 years of follow-up. Cancer causes \& control : CCC. 2019;30(4):311-22. doi:10.1007/s10552-019-01140-y.

20. Leon ME, Schinasi LH, Lebailly P, Beane Freeman LE, Nordby KC, Ferro G et al. Pesticide use and risk of nonHodgkin lymphoid malignancies in agricultural cohorts from France, Norway and the USA: a pooled analysis from the AGRICOH consortium. Int J Epidemiol. 2019. doi:10.1093/ije/dyz017.

21. Leveque-Morlais N, Tual S, Clin B, Adjemian A, Baldi I, Lebailly P. The AGRIculture and CANcer (AGRICAN) cohort study: enrollment and causes of death for the 2005-2009 period. Int Arch Occup Environ Health. 2015;88(1):61-73. doi:10.1007/s00420-014-0933-x.

22. Kristensen P, Andersen A, Irgens LM, Laake P, Bye AS. Incidence and risk factors of cancer among men and women in Norwegian agriculture. Scandinavian journal of work, environment \& health. 1996;22(1):14-26. 
This is an author-produced, peer-reviewed version of this article. The final, definitive version of this document can be found online at Synthetic Chemicals and Health, published by Springer. Copyright restrictions may apply. doi: 10.1007/s40572-020-00266-5

23. Andreotti G, Koutros S, Hofmann JN, Sandler DP, Lubin JH, Lynch CF et al. Glyphosate Use and Cancer Incidence in the Agricultural Health Study. Journal of the National Cancer Institute. 2018;110(5):509-16. doi:10.1093/jnci/djx233.

24. Sheppard L, Shaffer RM. Re: Glyphosate Use and Cancer Incidence in the Agricultural Health Study. JNCI: Journal of the National Cancer Institute. 2018;111(2):214-5. doi:10.1093/jnci/djy200.

25. Lerro CC, Andreotti G, Koutros S, Lee WJ, Hofmann JN, Sandler DP et al. Alachlor Use and Cancer Incidence in the Agricultural Health Study: An Updated Analysis. Journal of the National Cancer Institute. 2018;110(9):950-8. doi:10.1093/jnci/djy005.

26. Acquavella J, Olsen G, Cole P, Ireland B, Kaneene J, Schuman S et al. Cancer among farmers: a meta-analysis. Annals of epidemiology. 1998;8(1):64-74.

27. Boulanger M, Tual S, Lemarchand C, Guizard AV, Delafosse P, Marcotullio E et al. Lung cancer risk and occupational exposures in crop farming: results from the AGRIculture and CANcer (AGRICAN) cohort. Occup Environ Med. 2018;75(11):776-85. doi:10.1136/oemed-2017-104976.

28. Piel C, Pouchieu C, Migault L, Beziat B, Boulanger M, Bureau M et al. Increased risk of central nervous system tumours with carbamate insecticide use in the prospective cohort AGRICAN. Int J Epidemiol. 2018. doi:10.1093/ije/dyy246.

29. Zhang L, Rana I, Shaffer RM, Taioli E, Sheppard L. Exposure to glyphosate-based herbicides and risk for nonHodgkin lymphoma: A meta-analysis and supporting evidence. Mutation Research/Reviews in Mutation Research. 2019;781:186-206. doi:https://doi.org/10.1016/j.mrrev.2019.02.001.

30. Phillips DH, Arlt VM. Genotoxicity: damage to DNA and its consequences. Exs. 2009;99:87-110.

31. Bolognesi C. Genotoxicity of pesticides: a review of human biomonitoring studies. Mutation research. 2003;543(3):251-72. doi:10.1016/s1383-5742(03)00015-2.

32. Møller P. The comet assay: ready for 30 more years. Mutagenesis. 2018;33(1):1-7.

33. Fenech M. The Micronucleus Assay Determination of Chromosomal Level DNA Damage. In: Martin CC (eds) Environmental Genomics. Methods in Molecular Biology(410). Humana Press.

34. Nandhakumar S, Parasuraman S, Shanmugam MM, Rao KR, Chand P, Bhat BV. Evaluation of DNA damage using single-cell gel electrophoresis (Comet Assay). Journal of pharmacology \& pharmacotherapeutics. 2011;2(2):107-111. doi:10.4103/0976-500X.81903

35. Collins AR. The comet assay for DNA damage and repair. Molecular biotechnology. 2004;26(3):249.

36. Fenech M, Kirsch-Volders M, Natarajan AT, Surralles J, Crott JW, Parry J, Norppa H, Eastmond DA, Tucker JD, Thomas P. Molecular mechanisms of micronucleus, nucleoplasmic bridge and nuclear bud formation in mammalian and human cells. Mutagenesis. 2011;26(1):125-132.

37. Hutter HP, Khan AW, Lemmerer K, Wallner P, Kundi M, Moshammer H. Cytotoxic and Genotoxic Effects of Pesticide Exposure in Male Coffee Farmworkers of the Jarabacoa Region, Dominican Republic. Int J Environ Res Public Health. 2018;15(8). doi:10.3390/ijerph15081641.

38. Kahl VFS, da Silva FR, Alves JDS, da Silva GF, Picinini J, Dhillon VS et al. Role of PON1, SOD2, OGG1, XRCC1, and XRCC4 polymorphisms on modulation of DNA damage in workers occupationally exposed to pesticides. Ecotoxicol Environ Saf. 2018;159:164-71. doi:10.1016/j.ecoenv.2018.04.052.

39. Hayat K, Afzal M, Aqueel MA, Ali S, Saeed MF, Qureshi AK et al. Insecticide toxic effects and blood biochemical alterations in occupationally exposed individuals in Punjab, Pakistan. Sci Total Environ. 2019;655:102-11. doi:10.1016/j.scitotenv.2018.11.175.

40. Saad-Hussein A, Beshir S, Taha MM, Shahy EM, Shaheen W, Abdel-Shafy EA et al. Early prediction of liver carcinogenicity due to occupational exposure to pesticides. Mutation research Genetic toxicology and environmental mutagenesis. 2019;838:46-53. doi:10.1016/j.mrgentox.2018.12.004.

41. Dhananjayan V, Ravichandran B, Panjakumar K, Kalaiselvi K, Rajasekar K, Mala A et al. Assessment of genotoxicity and cholinesterase activity among women workers occupationally exposed to pesticides in tea garden. Mutation research. 2019;841:1-7. doi:10.1016/j.mrgentox.2019.03.002.

42. Intranuovo G, Schiavulli N, Cavone D, Birtolo F, Cocco P, Vimercati L et al. Assessment of DNA damages in lymphocytes of agricultural workers exposed to pesticides by comet assay in a cross-sectional study. Biomarkers : biochemical indicators of exposure, response, and susceptibility to chemicals. 2018;23(5):462-73. doi:10.1080/1354750x.2018.1443513.

43. Sailaja N, Chandrasekhar M, Rekhadevi P, Mahboob M, Rahman M, Vuyyuri SB, Danadevi K, Hussain SA, Grover P. Genotoxic evaluation of workers employed in pesticide production. Mutation Research. 2006;609:74-80. doi: 10.1016/j.mrgentox.2006.06.022. 
This is an author-produced, peer-reviewed version of this article. The final, definitive version of this document can be found online at Synthetic Chemicals and Health, published by Springer. Copyright restrictions may apply. doi: 10.1007/s40572-020-00266-5

44. Martínez-Valenzuela C, Gómez-Arroyo S, Villalobos-Pietrini R, Waliszewski S, Calderón-Segura ME, FélixGastélum R, Álvarez-Torres A. Genotoxic biomonitoring of agricultural workers exposed to pesticides in the north of Sinaloa State, Mexico. Environment International. 2009;35(8):1155-1159.

45. Pastor S, Gutierrez S, Creus A, Cebulska-Wasilewska A, Marcos R. Micronuclei in peripheral blood lymphocytes and buccal epithelial cells of Polish farmers exposed to pesticides. Mutation Research. 2001;495:147-156. doi: 10.1016/S1383-5718(01)00206-6.

46. Cattelan MDP, Maurer P, Garcia F, Berro LF, Machado MM, Manfredini V et al. Occupational exposure to pesticides in family agriculture and the oxidative, biochemical and hematological profile in this agricultural model. Life sciences. 2018;203:177-83. doi:10.1016/j.lfs.2018.04.038.

47. Sapbamrer R, Khacha-Ananda S, Sittitoon N, Wunnapuk K, Seesen M, Sidthilaw S et al. A longitudinal followup study of oxidative stress and DNA damage among farmers exposed to pesticide mixtures. Environmental science and pollution research international. 2019;26(13):13185-94. doi:10.1007/s11356019-04650-z.

48. Rodrigues MA. Automation of the in vitro micronucleus assay using the Imagestream ${ }^{\circledR}$ imaging flow cytometer. Cytometry. Part A: The journal of the International Society for Analytical Cytology. 2018;93(7):706-726. doi:10.1002/cyto.a.23493.

49. Langie SA, Koppen G, Desaulniers D, Al-Mulla F, Al-Temaimi R, Amedei A, Azqueta A, Bisson WH, Brown D, Brunborg G, Charles AK et al. Causes of genome instability: the effect of low dose chemical exposures in modern society. Carcinogenesis. 2015;36(Suppl_1):S61-88.

50. Bausinger J, Speit G. The impact of lymphocyte isolation on induced DNA damage in human blood samples measured by the comet assay. Mutagenesis. 2016;31(5):567-72.

51. Lozano-Paniagua D, Parron T, Alarcon R, Requena M, Gil F, Lopez-Guarnido O et al. Biomarkers of oxidative stress in blood of workers exposed to non-cholinesterase inhibiting pesticides. Ecotoxicol Environ Saf. 2018;162:121-8. doi:10.1016/j.ecoenv.2018.06.074.

52. Halliwell B, Whiteman M. Measuring reactive species and oxidative damage in vivo and in cell culture: how should you do it and what do the results mean? British journal of pharmacology. 2004;142(2):231-55. doi:10.1038/sj.bjp.0705776.

53. Frijhoff J, Winyard PG, Zarkovic N, Davies SS, Stocker R, Cheng D et al. Clinical Relevance of Biomarkers of Oxidative Stress. Antioxidants \& redox signaling. 2015;23(14):1144-70. doi:10.1089/ars.2015.6317.

54. Butterfield DA. Amyloid beta-peptide [1-42]-associated free radical-induced oxidative stress and neurodegeneration in Alzheimer's disease brain: mechanisms and consequences. Current medicinal chemistry. 2003;10(24):2651-9.

55. Chowienczyk PJ, Brett SE, Gopaul NK, Meeking D, Marchetti M, Russell-Jones DL et al. Oral treatment with an antioxidant (raxofelast) reduces oxidative stress and improves endothelial function in men with type II diabetes. Diabetologia. 2000;43(8):974-7. doi:10.1007/s001250051478.

56. Weinberg F, Chandel NS. Reactive oxygen species-dependent signaling regulates cancer. Cellular and molecular life sciences : CMLS. 2009;66(23):3663-73. doi:10.1007/s00018-009-0099-y.

57. Muhammad S, Bierhaus A, Schwaninger M. Reactive oxygen species in diabetes-induced vascular damage, stroke, and Alzheimer's disease. Journal of Alzheimer's disease : JAD. 2009;16(4):775-85. doi:10.3233/jad2009-0982.

58. Birben E, Sahiner UM, Sackesen C, Erzurum S, Kalayci O. Oxidative stress and antioxidant defense. The World Allergy Organization journal. 2012;5(1):9-19. doi:10.1097/WOX.0b013e3182439613.

59. Bouchard MF, Bellinger DC, Wright RO, Weisskopf MG. Attention-deficit/hyperactivity disorder and urinary metabolites of organophosphate pesticides. Pediatrics. 2010;125(6):e1270-e7.

60. Bouchard MF, Chevrier J, Harley KG, Kogut K, Vedar M, Calderon N et al. Prenatal exposure to organophosphate pesticides and IQ in 7-year-old children. Environmental health perspectives. 2011;119(8):1189.

61. Engel SM, Berkowitz GS, Barr DB, Teitelbaum SL, Siskind J, Meisel SJ et al. Prenatal organophosphate metabolite and organochlorine levels and performance on the Brazelton Neonatal Behavioral Assessment Scale in a multiethnic pregnancy cohort. American journal of epidemiology. 2007;165(12):1397-404.

62. Engel SM, Bradman A, Wolff MS, Rauh VA, Harley KG, Yang JH et al. Prenatal Organophosphorus Pesticide Exposure and Child Neurodevelopment at 24 Months: An Analysis of Four Birth Cohorts. Environ Health Perspect. 2016;124(6):822-30. doi:10.1289/ehp.1409474.

63. Engel SM, Wetmur J, Chen J, Zhu C, Barr DB, Canfield RL et al. Prenatal exposure to organophosphates, paraoxonase 1, and cognitive development in childhood. Environ Health Perspect. 2011;119(8):1182-8. doi:10.1289/ehp.1003183. 
This is an author-produced, peer-reviewed version of this article. The final, definitive version of this document can be found online at Synthetic Chemicals and Health, published by Springer. Copyright restrictions may apply. doi: 10.1007/s40572-020-00266-5

64. Furlong MA, Barr DB, Wolff MS, Engel SM. Prenatal exposure to pyrethroid pesticides and childhood behavior and executive functioning. Neurotoxicology. 2017;62:231-8. doi:10.1016/j.neuro.2017.08.005.

65. Baltazar MT, Dinis-Oliveira RJ, de Lourdes Bastos M, Tsatsakis AM, Duarte JA, Carvalho F. Pesticides exposure as etiological factors of Parkinson's disease and other neurodegenerative diseases--a mechanistic approach. Toxicol Lett. 2014;230(2):85-103. doi:10.1016/j.toxlet.2014.01.039.

66. Rohlman DS, Ismail A, Bonner MR, Abdel Rasoul G, Hendy O, Ortega Dickey L et al. Occupational pesticide exposure and symptoms of attention deficit hyperactivity disorder in adolescent pesticide applicators in Egypt. Neurotoxicology. 2019;74:1-6. doi:10.1016/j.neuro.2019.05.002.

67. Guytingco A, Thepaksorn P, Neitzel RL. Prevalence of Abnormal Serum Cholinesterase and Associated Symptoms from Pesticide Exposure among Agricultural Workers in the South of Thailand. J Agromedicine. 2018;23(3):270-8. doi:10.1080/1059924x.2018.1470049.

68. Freire C, Koifman S. Pesticides, depression and suicide: a systematic review of the epidemiological evidence. Int J Hyg Environ Health. 2013;216(4):445-60. doi:10.1016/j.ijheh.2012.12.003.

69. Meyer A, Koifman S, Koifman RJ, Moreira JC, de Rezende Chrisman J, Abreu-Villaca Y. Mood disorders hospitalizations, suicide attempts, and suicide mortality among agricultural workers and residents in an area with intensive use of pesticides in Brazil. J Toxicol Environ Health A. 2010;73(13-14):866-77. doi:10.1080/15287391003744781.

70. Wesseling C, van Wendel de Joode B, Keifer M, London L, Mergler D, Stallones L. Symptoms of psychological distress and suicidal ideation among banana workers with a history of poisoning by organophosphate or nmethyl carbamate pesticides. Occup Environ Med. 2010;67(11):778-84. doi:10.1136/oem.2009.047266.

71. MacFarlane E, Simpson P, Benke G, Sim MR. Suicide in Australian pesticide-exposed workers. Occupational medicine (Oxford, England). 2011;61(4):259-64. doi:10.1093/occmed/kqr031.

72. Serrano-Medina A, Ugalde-Lizarraga A, Bojorquez-Cuevas MS, Garnica-Ruiz J, Gonzalez-Corral MA, GarciaLedezma A et al. Neuropsychiatric Disorders in Farmers Associated with Organophosphorus Pesticide Exposure in a Rural Village of Northwest Mexico. Int J Environ Res Public Health. 2019;16(5). doi:10.3390/ijerph16050689.

73. Shrestha S, Kamel F, Umbach DM, Freeman LEB, Koutros S, Alavanja M et al. High Pesticide Exposure Events and Olfactory Impairment among U.S. Farmers. Environ Health Perspect. 2019;127(1):17005. doi:10.1289/ehp3713.

74. Chen H, Shrestha S, Huang X, Jain S, Guo X, Tranah GJ et al. Olfaction and incident Parkinson disease in US white and black older adults. Neurology. 2017;89(14):1441-7. doi:10.1212/wnl.0000000000004382.

75. Yaffe K, Freimer D, Chen H, Asao K, Rosso A, Rubin S et al. Olfaction and risk of dementia in a biracial cohort of older adults. Neurology. 2017;88(5):456-62. doi:10.1212/wnl.0000000000003558.

76. Damalas CA, Koutroubas SD. Farmers' Exposure to Pesticides: Toxicity Types and Ways of Prevention. Toxics. 2016;4(1):1. doi:10.3390/toxics4010001.

77. Hoppin Jane A, Umbach David M, Long S, London Stephanie J, Henneberger Paul K, Blair A et al. Pesticides are Associated with Allergic and Non-Allergic Wheeze among Male Farmers. Environmental Health Perspectives. 2017;125(4):535-43. doi:10.1289/EHP315.

78. Mamane A, Baldi I, Tessier JF, Raherison C, Bouvier G. Occupational exposure to pesticides and respiratory health. European respiratory review : an official journal of the European Respiratory Society. 2015;24(136):306-19. doi:10.1183/16000617.00006014.

79. Buralli RJ, Ribeiro H, Mauad T, Amato-Lourenco LF, Salge JM, Diaz-Quijano FA et al. Respiratory Condition of Family Farmers Exposed to Pesticides in the State of Rio de Janeiro, Brazil. Int J Environ Res Public Health. 2018;15(6). doi:10.3390/ijerph15061203.

80. Starling AP, Umbach DM, Kamel F, Long S, Sandler DP, Hoppin JA. Pesticide use and incident diabetes among wives of farmers in the Agricultural Health Study. Occup Environ Med. 2014;71(9):629-35. doi:10.1136/oemed-2013-101659.

81. Evangelou E, Ntritsos G, Chondrogiorgi M, Kavvoura FK, Hernandez AF, Ntzani EE et al. Exposure to pesticides and diabetes: A systematic review and meta-analysis. Environ Int. 2016;91:60-8. doi:10.1016/j.envint.2016.02.013.

82. Montgomery MP, Kamel F, Saldana TM, Alavanja MC, Sandler DP. Incident diabetes and pesticide exposure among licensed pesticide applicators: Agricultural Health Study, 1993-2003. Am J Epidemiol. 2008;167(10):1235-46. doi:10.1093/aje/kwn028.

83. Park S, Kim SK, Kim JY, Lee K, Choi JR, Chang SJ et al. Exposure to pesticides and the prevalence of diabetes in a rural population in Korea. Neurotoxicology. 2019;70:12-8. doi:10.1016/j.neuro.2018.10.007. 
This is an author-produced, peer-reviewed version of this article. The final, definitive version of this document can be found online at Synthetic Chemicals and Health, published by Springer. Copyright restrictions may apply. doi: 10.1007/s40572-020-00266-5

84. Kongtip P, Nankongnab N, Tipayamongkholgul M, Bunngamchairat A, Yimsabai J, Pataitiemthong A et al. A Cross-Sectional Investigation of Cardiovascular and Metabolic Biomarkers among Conventional and Organic Farmers in Thailand. Int J Environ Res Public Health. 2018;15(11). doi:10.3390/ijerph15112590.

85. Campos E, Freire C. Exposure to non-persistent pesticides and thyroid function: A systematic review of epidemiological evidence. Int J Hyg Environ Health. 2016;219(6):481-97. doi:10.1016/j.ijheh.2016.05.006.

86. Goldner WS, Sandler DP, Yu F, Hoppin JA, Kamel F, Levan TD. Pesticide use and thyroid disease among women in the Agricultural Health Study. Am J Epidemiol. 2010;171(4):455-64. doi:10.1093/aje/kwp404.

87. Goldner WS, Sandler DP, Yu F, Shostrom V, Hoppin JA, Kamel F et al. Hypothyroidism and pesticide use among male private pesticide applicators in the agricultural health study. J Occup Environ Med. 2013;55(10):1171-8. doi:10.1097/JOM.0b013e31829b290b.

88. Lerro CC, Beane Freeman LE, DellaValle CT, Kibriya MG, Aschebrook-Kilfoy B, Jasmine F et al. Occupational pesticide exposure and subclinical hypothyroidism among male pesticide applicators. Occup Environ Med. 2018;75(2):79-89. doi:10.1136/oemed-2017-104431.

89. Shrestha S, Parks CG, Goldner WS, Kamel F, Umbach DM, Ward MH et al. Pesticide Use and Incident Hypothyroidism in Pesticide Applicators in the Agricultural Health Study. Environ Health Perspect. 2018;126(9):97008. doi:10.1289/ehp3194.

90. Brix TH, Kyvik KO, Hegedüs L. Validity of self-reported hyperthyroidism and hypothyroidism: comparison of self-reported questionnaire data with medical record review. Thyroid. 2001;11(8):769-73.

91. Bernieri T, Rodrigues D, Barbosa IR, Ardenghi PG, Basso da Silva L. Occupational exposure to pesticides and thyroid function in Brazilian soybean farmers. Chemosphere. 2019;218:425-9. doi:10.1016/j.chemosphere.2018.11.124.

92. Chaker L, Bianco AC, Jonklaas J, Peeters RP. Hypothyroidism. Lancet. 2017;390(10101):1550-62. doi:10.1016/s0140-6736(17)30703-1. 
This is an author-produced, peer-reviewed version of this article. The final, definitive version of this document can be found online at Synthetic Chemicals and Health, published by Springer. Copyright restrictions may apply. doi: 10.1007/s40572-020-00266-5

\begin{tabular}{|c|c|c|c|c|}
\hline Author & Participants & Exposures and Assessments & Outcomes and Assessments & Key Results (all confidence intervals at $95 \%$ ) \\
\hline \multicolumn{5}{|c|}{ Cancer } \\
\hline $\begin{array}{l}\text { Lerro CC et al. } \\
\text { April } 2019 \text { [19] }\end{array}$ & $\begin{array}{l}\text { Agricultural Health Study (AHS): } \\
89,565 \text { private and commercial } \\
\text { pesticide applicators and } \\
\text { spouses, from North Carolina } \\
\text { and lowa, recruited from } 1993 \\
\text { to } 1997\end{array}$ & $\begin{array}{l}\text { Self-administered questionnaires on } \\
\text { farm life \& agricultural practices, types } \\
\text { of crops \& livestock, pesticide use/use } \\
\text { of }>50 \text { individual pesticide active } \\
\text { ingredients }\end{array}$ & $\begin{array}{l}\text { Incident cancer cases from NC } \\
\text { and IA state cancer registries }\end{array}$ & $\begin{array}{l}\text { All cancer sites: } \\
\text { SIR (private applicators)=0.91, Cl } 0.89-0.93 \\
\text { SIR (commercial applicators)=0.83, Cl } 0.76-0.92 \\
\text { Lip cancer: } \\
\text { SIR (private applicators)=2.22, Cl } 1.71-2.84 \\
\text { Prostate cancer: } \\
\text { SIR (private applicators)=1.15, Cl } 1.11-1.19 \\
\text { B-cell lymphomas overall: } \\
\text { SIR (private applicators)=1.12, Cl } 1.03-1.21 \\
\text { Chronic lymphocytic leukemia: } \\
\text { SIR (private applicators)=1.17, Cl } 1.00-1.36 \\
\text { Acute myeloid leukemia: } \\
\text { SIR (private applicators)=1.29, Cl } 1.03-1.59\end{array}$ \\
\hline $\begin{array}{l}\text { Leon ME et al. } \\
\text { March } 2019 \text { [20] }\end{array}$ & $\begin{array}{l}\text { Subset of the Agricultural } \\
\text { Health Study (AHS), including: } \\
\text { 57,310 private and commercial } \\
\text { pesticide applicators from } \\
\text { North Carolina and lowa, } \\
\text { recruited from } 1993 \text { to } 1997 \\
\text { Agriculture and Cancer } \\
\text { (AGRICAN): } \\
\text { 181,747 active and retired farm } \\
\text { workers in France, recruited } \\
\text { from } 2005-2007 \\
\text { Subset of the Cancer in the } \\
\text { Norwegian Agricultural } \\
\text { Population (CNAP), including: } \\
\text { 147,134 farm holders in } \\
\text { Norway, based on censuses in } \\
\text { 1969, 1974, 1979, 1985, } 1989\end{array}$ & $\begin{array}{l}\text { AHS: self-administered enrollment } \\
\text { questionnaires on farm life \& } \\
\text { agricultural practices, types of crops \& } \\
\text { livestock, pesticide use/use of }>50 \\
\text { individual pesticide active ingredients, } \\
5 \text { year follow-up questionnaires on } \\
\text { pesticide use since enrollment } \\
\text { AGRICAN: self-administered } \\
\text { questionnaires on cultivating } 13 \text { crops } \\
\text { and raising } 5 \text { animal species and } \\
\text { performance of pesticide treatment } \\
\text { tasks, crossed with country-specific- } \\
\text { crop-exposure matrices } \\
\text { CNAP: census data on type of crops } \\
\text { and livestock produced the preceding } \\
\text { year, acreage, technology, pesticide } \\
\text { expenses and pesticide spraying } \\
\text { equipment, crossed with country- } \\
\text { specific-crop-exposure-matrices }\end{array}$ & $\begin{array}{l}\text { First incident non-Hodgkin's } \\
\text { lymphoma (NHL) during follow- } \\
\text { up: } \\
\text { AHS: North Carolina and lowa } \\
\text { cancer and mortality registries } \\
\text { and the National Death Index } \\
\text { AGRICAN: French cancer and } \\
\text { mortality registries and the } \\
\text { National Death Index } \\
\text { CNAP: National Cancer Registry of } \\
\text { Norway }\end{array}$ & $\begin{array}{l}\text { NHL overall \& ever use of terbufos: } \\
\text { mHR(AGRICAN and AHS)=1.18, CI 1.00 - 1.39; } \\
\text { Chronic lymphocytic leukemia/small lymphocytic lymphoma \& } \\
\text { ever use of deltamethrin: } \\
\text { mHR (AGRICAN and CNAP)=1.48, Cl } 1.06-2.07 \\
\text { Diffuse large B-cell lymphoma \& ever use of glyphosate: } \\
\text { mHR=1.36, Cl } 1.00-1.85\end{array}$ \\
\hline
\end{tabular}


This is an author-produced, peer-reviewed version of this article. The final, definitive version of this document can be found online at Synthetic Chemicals and Health, published by Springer. Copyright restrictions may apply. doi: 10.1007/s40572-020-00266-5

\begin{tabular}{|c|c|c|c|c|}
\hline $\begin{array}{l}\text { Andreotti G et } \\
\text { al. May } 2018 \\
\text { [23] }\end{array}$ & $\begin{array}{l}\text { Subset of the Agricultural } \\
\text { Health Study (AHS): } \\
54,251 \text { pesticide applicators } \\
\text { from North Carolina and lowa, } \\
\text { recruited from 1993-1997, 63\% } \\
\text { of whom participated in a } \\
\text { follow up phone interview } 5 \\
\text { years after enrollment }\end{array}$ & $\begin{array}{l}\text { Ever/never use, lifetime days of use } \\
\text { (days per year } \times \text { number of years), and } \\
\text { intensity-weighted lifetime days } \\
\text { (lifetime days } \times \text { intensity score) use of } \\
\text { glyphosate from questionnaires at } \\
\text { enrollment and follow-up }\end{array}$ & $\begin{array}{l}\text { Incident cancer cases from North } \\
\text { Carolina and lowa state cancer } \\
\text { registries }\end{array}$ & $\begin{array}{l}\text { Highest quartile of glyphosate exposure to no exposure: } \\
\text { Total cancer: } \\
\text { RR=0.99, Cl } 0.91-1.08 \\
\text { Hematopoietic or lymphatic malignancies: } \\
\text { RR=1.00, Cl } 0.74-1.34 \\
\text { Non-Hodgkin lymphoma: } \\
\text { RR=0.87, Cl } 0.64-1.20 \\
\text { Multiple myeloma: } \\
R R=0.87, \mathrm{Cl} 0.45-1.69\end{array}$ \\
\hline $\begin{array}{l}\text { Lerro CC et al. } \\
\text { Sept } 2018 \text { [25] }\end{array}$ & $\begin{array}{l}\text { Subset of the Agricultural } \\
\text { Health Study (AHS): } \\
49,685 \text { pesticide applicators } \\
\text { from North Carolina and lowa, } \\
\text { recruited from 1993-1997, 63\% } \\
\text { of whom participated in a } \\
\text { follow up phone interview } 5 \\
\text { years after enrollment }\end{array}$ & $\begin{array}{l}\text { Cumulative lifetime days (sum of days } \\
\text { of alachlor use reported at enrollment } \\
\text { through the year last farmed reported } \\
\text { at follow-up) and intensity-weighted } \\
\text { days (cumulative lifetime days } \\
\text { multiplied by an intensity-weighting } \\
\text { factor) from questionnaires at } \\
\text { enrollment and follow-up on alachlor } \\
\text { use }\end{array}$ & $\begin{array}{l}\text { Incident cancer cases from North } \\
\text { Carolina and lowa state cancer } \\
\text { registries }\end{array}$ & $\begin{array}{l}\text { Laryngeal cancer \& alachlor exposure: } \\
\text { RR (Quartile } 2,661-1762 \text { intensity-weighted days compared } \\
\text { to no exposure) }=4.68, \mathrm{Cl} 1.95-11.23 \\
\text { RR (Quartile } 3,1763-5075 \text { intensity-weighted days compared } \\
\text { to no exposure) }=6.04, \mathrm{Cl} 2.44-14.99 \\
\text { RR (Quartile } 4,>5075 \text { intensity-weighted days compared to no } \\
\text { exposure) }=7.10,2.58-19.53\end{array}$ \\
\hline $\begin{array}{l}\text { Boulanger M et } \\
\text { al. May } 2018 \\
\text { [27] }\end{array}$ & $\begin{array}{l}\text { Agriculture and Cancer } \\
\text { (AGRICAN): } \\
\text { 148,044 active and retired farm } \\
\text { workers in France, recruited } \\
\text { from 2005-2007 }\end{array}$ & $\begin{array}{l}\text { Self-administered questionnaires on } \\
\text { lifetime history of agricultural } \\
\text { activities, cultivating } 13 \text { crops and } \\
\text { raising } 5 \text { animal species, performance } \\
\text { of harvesting, pesticide application, } \\
\text { seed treatment, seedling, and/or re- } \\
\text { entry tasks }\end{array}$ & $\begin{array}{l}\text { Incident lung cancer cases from } \\
\text { French cancer registries }\end{array}$ & $\begin{array}{l}\text { Adenocarcinomas \& winegrowing: } \\
\text { HR (Ever vineyard farm work to never vineyard farm } \\
\text { work)=1.27, Cl } 0.94-1.72 \\
\text { Small cell lung cancers \& pea/field beans: } \\
\text { HR (Ever pesticide application to never pesticide } \\
\text { application)=2.38, Cl } 1.07 \text { - } 5.28 \\
\text { Squamous cell carcinomas \& beets: } \\
\text { HR (Ever pesticide application to never pesticide } \\
\text { application)=1.47, Cl } 0.92-2.34 \\
\text { Squamous cell carcinomas \& sunflowers: } \\
\text { HR (Ever harvester to never harvester)=1.61, Cl } 0.91-2.86 \\
\text { Squamous cell carcinomas \& fruit-trees: } \\
\text { HR (Ever pruner to never pruner)=1.44, Cl } 0.92-2.27 \\
\text { Overall lung cancer \& corn: } \\
\text { HR (Ever grower to never grower)=0.76, Cl } 0.62-0.92 \\
\text { Overall lung cancer \& wheat/barley: } \\
\text { HR (Ever grower to never grower)=0.85, Cl } 0.70-1.04\end{array}$ \\
\hline $\begin{array}{l}\text { Peil C et al. } \\
\text { November } 2018 \\
\text { [28] }\end{array}$ & $\begin{array}{l}\text { Agriculture and Cancer } \\
\text { (AGRICAN): } \\
\text { 181,842 active and retired farm } \\
\text { workers in France, recruited } \\
\text { from 2005-2007 }\end{array}$ & $\begin{array}{l}\text { Self-administered questionnaires on } \\
\text { cultivating } 13 \text { crops and raising } 5 \\
\text { animal species and occupational } \\
\text { activities }\end{array}$ & $\begin{array}{l}\text { Incident central nervous system } \\
\text { cancer cases (gliomas and } \\
\text { meningiomas) from French cancer } \\
\text { registries and the National Death } \\
\text { Index }\end{array}$ & $\begin{array}{l}\text { CNS tumors \& exposure to all carbamates: } \\
\mathrm{HR}=1.47, \mathrm{Cl} 1.03-2.10\end{array}$ \\
\hline
\end{tabular}




\section{Table 2. Studies regarding agricultural occupational pesticide exposure and other health outcomes: May 15, 2018 - May 14, 2019}

\begin{tabular}{|c|c|c|c|c|}
\hline Author & Participants & Exposures and Assessments & Outcomes and Assessments & Key Results (all confidence intervals at 95\%) \\
\hline \multicolumn{5}{|c|}{ DNA Damage and Oxidative Stress } \\
\hline $\begin{array}{l}\text { Hutter HP et al. } \\
\text { August } 2018 \\
{[37]}\end{array}$ & $\begin{array}{l}38 \text { pesticide sprayers and } 33 \\
\text { farmers not exposed to } \\
\text { pesticides from coffee } \\
\text { production farms in the } \\
\text { Dominican Republic }\end{array}$ & $\begin{array}{l}\text { Pesticide sprayers were considered } \\
\text { exposed, additional information was } \\
\text { collected from a questionnaire on } \\
\text { demographics and indicators of } \\
\text { pesticide exposure including type and } \\
\text { duration }\end{array}$ & $\begin{array}{l}\text { Buccal cell samples analyzed for } \\
\text { genotoxic and cytotoxic effects: } \\
\text { micronuclei cells, total } \\
\text { micronuclei, nuclear buds \& } \\
\text { broken eggs, binucleated cells, } \\
\text { condensed chromatin, } \\
\text { karyorrhectic cells, karyolitic cells, } \\
\text { and pyknosis }\end{array}$ & $\begin{array}{l}\text { Micronuclei cells: } \\
\text { OR=3.098, Cl } 1.297-7.404 \\
\text { Total micronuclei: } \\
\text { OR=2.534, Cl } 1.219-5.226 \\
\text { Nuclear buds \& broken eggs: } \\
\text { OR=1.916, Cl } 1.448-2.536 \\
\text { Binucleated cells: } \\
\text { OR=1.412, Cl } 1.207-1.650\end{array}$ \\
\hline $\begin{array}{l}\text { Kahl SVF et al. } \\
\text { September } 2018 \\
{[38]}\end{array}$ & $\begin{array}{l}121 \text { tobacco farm workers } \\
\text { occupationally exposed to } \\
\text { pesticide mixtures and } 121 \text { non- } \\
\text { exposed non-farm workers in } \\
\text { Brazil }\end{array}$ & $\begin{array}{l}\text { Those with an occupation as a } \\
\text { tobacco farmer were considered } \\
\text { exposed to pesticides and completed } \\
\text { a questionnaire adapted from the } \\
\text { International Commission for } \\
\text { Protection against Environmental } \\
\text { Mutagens and Carcinogens }\end{array}$ & $\begin{array}{l}\text { Whole blood comet assay as well } \\
\text { as buccal cell micronucleus } \\
\text { cytome assay for damage index, } \\
\text { micronucleus, nuclear buds, } \\
\text { binucleated cells, and telomere } \\
\text { length; blood cotinine levels and } \\
\text { inorganic elements; thiobarbituric } \\
\text { acid reactive substances (TBARS) } \\
\text { and total equivalent antioxidant } \\
\text { capacity (TEAC); and various } \\
\text { polymorphisms }\end{array}$ & $\begin{array}{l}\text { Increased frequency of: } \\
\text { Damage index: } 22.1 \pm 1.6 \text { (exposed) vs. } 4.6 \pm 0.4 \text { (unexposed), } \\
p=<0.001 \\
\text { Micronucleus: } 25.3 \pm 2.9 \text { (exposed) vs. } 5.8 \pm 0.7 \text { (unexposed), } \\
p=<0.001 \\
\text { Nuclear buds: } 3.3 \pm 0.3 \text { (exposed) vs. } 1.1 \pm 0.1 \text { (unexposed), } \\
p=<0.001 \\
\text { Binucleated cells: } 7.2 \pm 0.5 \text { (exposed) vs } 5.4 \pm 0.4 \\
\text { (unexposed), } p=0.010 \\
\text { Exposed vs. non-exposed increased levels of oxidative stress } \\
\text { biomarkers: } \\
\text { TBARS: } p=<0.001 \\
\text { TEAC: } p=<0.001\end{array}$ \\
\hline $\begin{array}{l}\text { Hayat K et al. } \\
\text { November } 2018 \\
\text { [39] }\end{array}$ & $\begin{array}{l}\text { Pesticide industry workers } \\
\text { (formulators and packers), } \\
\text { pesticide sprayers, and controls } \\
\text { with no occupational exposure } \\
\text { to pesticides }\end{array}$ & $\begin{array}{l}\text { Pesticide industry workers and } \\
\text { sprayers were considered exposed to } \\
\text { pesticides }\end{array}$ & $\begin{array}{l}\text { Whole blood comet assay for tail } \\
\text { length and comet frequency, } \\
\text { pesticide residues in blood } \\
\text { samples, and hepatic and nervous } \\
\text { system enzymes }\end{array}$ & $\begin{array}{l}\text { Tail length }(\mu \mathrm{m}) \text { : } \\
16.88 \pm 8.57 \text { (industry workers) vs. } 16.33 \pm 3.78 \text { (sprayers) vs. } \\
6.53 \pm 2.75 \text { (controls), } p=<0.01 \\
\text { Comet frequency: } \\
17.56 \pm 11.55 \text { (industry workers) vs. } 15.76 \pm 9.37 \text { (sprayers) } \\
\text { vs. } 3.25 \pm 1.42 \text { (controls), } p=<0.01\end{array}$ \\
\hline $\begin{array}{l}\text { Saad-Hussein A } \\
\text { et al. February } \\
2019[40]\end{array}$ & $\begin{array}{l}50 \text { urban researchers using } \\
\text { pesticides in laboratories, } 50 \\
\text { rural pesticide sprayers, and } 50 \\
\text { urban researchers not } \\
\text { occupationally exposed to } \\
\text { pesticides and } 50 \text { rural controls } \\
\text { not occupationally exposed to } \\
\text { pesticides }\end{array}$ & $\begin{array}{l}\text { Urban researchers exposed to } \\
\text { pesticides in laboratories and rural } \\
\text { pesticide sprayers were considered } \\
\text { exposed }\end{array}$ & $\begin{array}{l}\text { Whole blood telomere length, } \\
\text { telomerase activity, comet assay } \\
\text { for tail length, percent DNA in tail, } \\
\text { and tail moment; GST genotypes; } \\
\text { liver tumor markers }\end{array}$ & 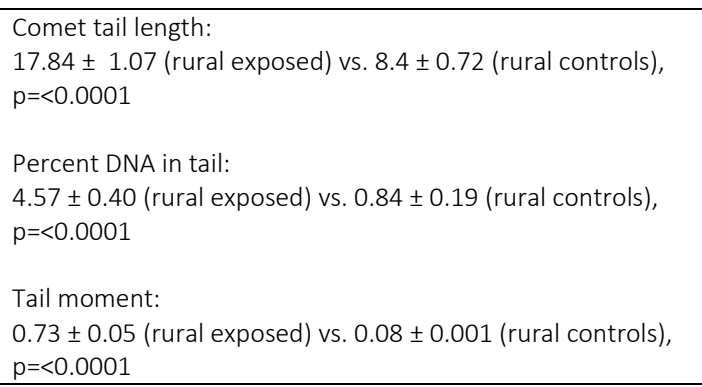 \\
\hline
\end{tabular}


This is an author-produced, peer-reviewed version of this article. The final, definitive version of this document can be found online at Synthetic Chemicals and Health, published by Springer. Copyright restrictions may apply. doi: 10.1007/s40572-020-00266-5

\begin{tabular}{|c|c|c|c|c|}
\hline $\begin{array}{l}\text { Dhananjayan V } \\
\text { et al. March } \\
2019[41]\end{array}$ & $\begin{array}{l}77 \text { tea garden workers exposed } \\
\text { to pesticide and } 66 \text { individuals } \\
\text { with no occupational exposure } \\
\text { to pesticides in India, recruited } \\
\text { from December } 2013 \text { to } \\
\text { February } 2014\end{array}$ & $\begin{array}{l}\text { Women who had worked in tea } \\
\text { gardens for at least } 3 \text { years were } \\
\text { considered exposed to pesticides. } \\
\text { Participants completed a } \\
\text { questionnaire on demographics, } \\
\text { health, lifestyle, and occupational } \\
\text { details }\end{array}$ & $\begin{array}{l}\text { Peripheral lymphocyte comet } \\
\text { assay for percent DNA in tail, tail } \\
\text { length, tail moment, and olive tail } \\
\text { moment; and cholinesterase } \\
\text { activity in erythrocytes and blood } \\
\text { plasma }\end{array}$ & $\begin{array}{l}\text { Mean tail length }(\mu \mathrm{m}) \text { : } \\
9.45 \pm 5.28 \text { (exposed) vs. } 2.09 \pm 0.95 \text { (unexposed), } p=<0.05 \\
\text { Percent DNA in tail: } \\
13.1 \pm 8.17 \text { (exposed) vs. } 2.26 \pm 1.63 \text { (unexposed), } p=<0.05 \\
\text { Tail moment ( } \mu \mathrm{m} \text { ): } \\
3.19 \pm 2.29 \text { (exposed) vs. } 0.20 \pm 0.12 \text { (unexposed), } p=<0.05 \\
\text { Olive tail moment ( } \mu \mathrm{m} \text { ): } \\
4.15 \pm 2.18 \text { (exposed) vs. } 0.59 \pm 0.44 \text { (unexposed), } p=<0.05\end{array}$ \\
\hline $\begin{array}{l}\text { Intranuovo G et } \\
\text { al. July } 2018 \text { [42] }\end{array}$ & $\begin{array}{l}22 \text { agricultural workers exposed } \\
\text { to pesticides and } 24 \text { non- } \\
\text { agricultural hematologic } \\
\text { outpatients from the provinces } \\
\text { of Bari and Taranto, Italy }\end{array}$ & $\begin{array}{l}\text { Agricultural workers were considered } \\
\text { exposed to pesticides. Intensity level } \\
\text { score for pesticide exposure } \\
\text { calculated based on questionnaire } \\
\text { responses regarding pesticide mixing, } \\
\text { application, personal hygiene, use of } \\
\text { protective equipment, repair of } \\
\text { pesticide tanks, and use of tractors } \\
\text { with cabins }\end{array}$ & $\begin{array}{l}\text { Peripheral lymphocyte comet } \\
\text { assay for tail moment, tail area, } \\
\text { head DNA, tail DNA, integral } \\
\text { intensity, head radius, tail length, } \\
\text { olive movement, and head area }\end{array}$ & $\begin{array}{l}\text { Odds of tail moment above } 75 \text { th percentile in exposed to } \\
\text { unexposed: } \\
\text { OR=5.77, Cl } 4.63-7.21 \\
\text { Odds of tail length above } 75 \text { th percentile in exposed to } \\
\text { unexposed: } \\
\text { OR=6.36, Cl } 5.1-7.95\end{array}$ \\
\hline $\begin{array}{l}\text { Cattelan MDP et } \\
\text { al. June } 2018 \\
\text { [46] }\end{array}$ & $\begin{array}{l}84 \text { farmers reporting } \\
\text { occupational pesticide use and } \\
68 \text { farmers not reporting } \\
\text { occupational pesticide use in } \\
\text { Brazil }\end{array}$ & $\begin{array}{l}\text { Farmers reporting pesticide use were } \\
\text { considered exposed, based on a } \\
\text { questionnaire regarding pesticide use } \\
\text { and occupational practices }\end{array}$ & $\begin{array}{l}\text { Blood samples to measure } \\
\text { thiobarbituric acid reactive } \\
\text { substances (TBARS) and } \\
\text { carbonylation of proteins } \\
\text { (Carbonyl); superoxide dismutase } \\
\text { (SOD), catalase (CAT), glutathione } \\
\text { reductase (GSH), and glutathione } \\
\text { peroxidase (GPX); and frequency } \\
\text { of micronuclei in leukocytes }\end{array}$ & $\begin{array}{l}\text { Micronuclei frequency: } \\
0.24 \% \text { (exposed) vs. } 0.12 \% \text { (unexposed), } p=0.288 \\
\text { SOD activity: } \\
\text { decreased in exposed vs. unexposed, } p=<0.01 \\
\text { GSH activity: } \\
\text { decreased in exposed vs. unexposed, } p=<0.01 \\
\text { GPx activity: } \\
\text { decreased in exposed vs. unexposed, } p=<0.01 \\
\text { TBARS: } \\
\text { decreased in exposed vs. unexposed, } p=0.02\end{array}$ \\
\hline $\begin{array}{l}\text { Sapbamrer R et } \\
\text { al. May } 2019 \\
\text { [47] }\end{array}$ & 56 male farmers in Thailand & $\begin{array}{l}\text { In-person interview on demographics } \\
\text { and occupational exposures, and } \\
\text { blood samples collected pre- and } \\
\text { post- pesticide application seasons }\end{array}$ & $\begin{array}{l}\text { Peripheral leukocyte comet assay } \\
\text { for tail length and tail moment;, 8- } \\
\text { hydroxy-2'-deoxyguanosine (8- } \\
\text { OHdG) levels; superoxide } \\
\text { dismutase (SOD) activity }\end{array}$ & $\begin{array}{l}\text { Median tail length }(\mu \mathrm{m}): 5.66 \text { (pre-pesticide application } \\
\text { season) vs. } 5.67 \text { (post-pesticide application season), } p=0.867 \\
\text { Median tail moment }(\mu \mathrm{m}): 2.84 \text { (pre-pesticide application } \\
\text { season) vs. } 2.83 \text { (post-pesticide application season), } p=0.729 \\
\text { Median 8-OHdG ( } \mathrm{gg} / \mathrm{mL}): 8.31 \text { (pre-pesticide application } \\
\text { season) vs. } 7.20 \text { (post-pesticide application season), } p=0.757 \\
\text { Median SOD }(\mathrm{U} / \mathrm{mL}): 0.94 \text { (pre-pesticide application season) } \\
\text { vs. } 1.35 \text { (post-pesticide application season), } p=<0.001\end{array}$ \\
\hline
\end{tabular}


This is an author-produced, peer-reviewed version of this article. The final, definitive version of this document can be found online at Synthetic Chemicals and Health, published by Springer. Copyright restrictions may apply. doi: 10.1007/s40572-020-00266-5

\begin{tabular}{|c|c|c|c|c|}
\hline $\begin{array}{l}\text { Lozano- } \\
\text { Paniagua D et al. } \\
\text { October } 2018 \\
{[51]}\end{array}$ & $\begin{array}{l}175 \text { greenhouse workers } \\
\text { carrying out farming activities } \\
\text { (pruning, weeding, thinning, } \\
\text { and applying pesticides) and } 91 \\
\text { healthy individuals without } \\
\text { occupational exposure to } \\
\text { pesticides in Almeria, Spain }\end{array}$ & $\begin{array}{l}\text { Greenhouse workers were considered } \\
\text { exposed to pesticides. Analyses was } \\
\text { conducted for two crop seasons: low } \\
\text { pesticide exposure season (one to two } \\
\text { pesticide applications per month) and } \\
\text { high pesticide exposure season } \\
\text { (weekly pesticide applications) }\end{array}$ & $\begin{array}{l}\text { Blood samples to measure } \\
\text { thiobarbituric acid reactive } \\
\text { substances (TBARS), ferric } \\
\text { reducing ability of serum (FRAS), } \\
\text { total thiol groups (SHT), and } \\
\text { gamma-glutamyl transpeptidase } \\
\text { (GGT) and Paraoxonase } 1 \text { (PON1) }\end{array}$ & $\begin{array}{l}\text { Mean FRAS ( } \mu \mathrm{mol} / \mathrm{l}) \text { : } \\
\text { High exposure season: } 2.800 \pm 0.017 \text { (greenhouse workers) } \\
\text { vs. } 2.664 \pm 0.020 \text { (unexposed), } p=<0.001 \\
\text { Mean SHT ( } \mu \text { mol/l): } \\
\text { High exposure season: }-0.250 \pm 0.015 \text { (greenhouse workers) } \\
\text { vs. }-0.396 \pm 0.019 \text { (unexposed), } p=<0.001 \\
\text { Low exposure season: }-0.366 \pm 0.019 \text { (greenhouse workers) } \\
\text { vs. }-0.387 \pm 0.126 \text { (unexposed), } p=<0.001 \\
\text { Mean PON1 (U/I): } \\
\text { High exposure season: } 2.276 \pm 0.036 \text { (greenhouse workers) } \\
\text { vs. } 2.206 \pm 0.047 \text { (unexposed), } p=0.069 \\
\text { Low exposure season: } 2.231 \pm 0.033 \text { (greenhouse workers) vs. } \\
2.115 \pm 0.046 \text { (unexposed), } p=0.069\end{array}$ \\
\hline \multicolumn{5}{|c|}{ Neurological Disorders } \\
\hline $\begin{array}{l}\text { Rohlman DS et } \\
\text { al. May } 2019 \\
{[66]}\end{array}$ & $\begin{array}{l}98 \text { adolescents aged } 12-21 \\
\text { years, comprised of } 59 \text { pesticide } \\
\text { applicators working for the } \\
\text { Ministry of Agriculture in Egypt } \\
\text { and } 39 \text { non-applicators }\end{array}$ & $\begin{array}{l}\text { Pesticide applicated were considered } \\
\text { exposed to pesticides, measurements } \\
\text { were also done for urinary 3,5,6- } \\
\text { trichloro-2-pyridinol (TCPy) levels, a } \\
\text { biomarker of chlorpyrifos exposure, } \\
\text { and blood acetylcholinesterase (AChE) } \\
\text { and butyrylcholinesterase (BChE) } \\
\text { activity, biomarkers of } \\
\text { organophosphate exposure }\end{array}$ & $\begin{array}{l}\text { Symptoms of attention deficit } \\
\text { hyperactivity disorder (ADHD) } \\
\text { assessed by parental completion } \\
\text { of the Revised Short Form of } \\
\text { Conners' Parent Rating Scale }\end{array}$ & $\begin{array}{l}\text { ADHD symptoms: } \\
4.46 \pm 4.95 \text { (applicators) vs. } 1.44 \pm 2.18 \text { (non-applicators), } \\
p=<0.001 \\
\text { Positive dose-response effect for number of ADHD symptoms } \\
\text { and TCPy level: } \\
p=<0.001 \\
\text { Positive dose-response effect for number of ADHD symptoms } \\
\text { and AChE: } \\
p=<0.001 \\
\begin{array}{l}\text { Positive dose-response effect for number of ADHD symptoms } \\
\text { and BChE: } \\
p=<0.001\end{array}\end{array}$ \\
\hline $\begin{array}{l}\text { Guytingco A et } \\
\text { al. July } 2018 \text { [67] }\end{array}$ & $\begin{array}{l}\text { 6,118 agricultural workers in } \\
\text { Thailand completing a } \\
\text { questionnaire on occupational } \\
\text { pesticide use and pesticide } \\
\text { behavioral patterns, and } \\
\text { symptoms, among those } 3,431 \\
\text { providing a blood sample }\end{array}$ & $\begin{array}{l}\text { Blood acetylcholinesterase (AChE) } \\
\text { levels, a biomarker of } \\
\text { organophosphate pesticide exposure }\end{array}$ & $\begin{array}{l}\text { Self-reported symptoms of } \\
\text { dizziness, dry skin \& irritation, } \\
\text { fatigue, burning sensation in nose, } \\
\text { sore throat, cough, rash, } \\
\text { sweating, headache, } \\
\text { conjunctivitis, heart palpitations }\end{array}$ & $\begin{array}{l}\text { 12.5\% of participants had low AChE levels; } \\
\text { Prevalence of dizziness: } \\
\text { 12.4\% (abnormal AChE) vs. } 4.0 \% \text { (normal AChE), } p=<0.001 \\
\text { Prevalence of headache: } \\
\text { 3.3\% (abnormal AChE) vs. } 1.3 \% \text { (normal AChE), } p=0.010 \\
\text { Prevalence dry skin and irritation: } \\
\text { 10.5\% (abnormal AChE) vs. } 4.0 \% \text { (normal AChE), } p=<0.001\end{array}$ \\
\hline
\end{tabular}


This is an author-produced, peer-reviewed version of this article. The final, definitive version of this document can be found online at Synthetic Chemicals and Health, published by Springer. Copyright restrictions may apply. doi: 10.1007/s40572-020-00266-5

\begin{tabular}{|c|c|c|c|c|}
\hline $\begin{array}{l}\text { Serrano-Medina } \\
\text { A et al. February } \\
2019[72]\end{array}$ & $\begin{array}{l}140 \text { agricultural workers and } \\
100 \text { individuals not exposed to } \\
\text { pesticides in Mexico }\end{array}$ & $\begin{array}{l}\text { Agricultural workers were considered } \\
\text { exposed to pesticides, measurements } \\
\text { were also done for blood } \\
\text { acetylcholinesterase levels, a } \\
\text { biomarker of organophosphate } \\
\text { pesticide exposure }\end{array}$ & $\begin{array}{l}\text { Symptoms of neuropsychiatric } \\
\text { disorders as assessed by the Mini } \\
\text { International Neuropsychiatric } \\
\text { Interview Diagnostic Test (MINI) }\end{array}$ & $\begin{array}{l}\text { Depression diagnosis frequency: } \\
\text { 14.3\% (exposed) vs. 3.0\% (unexposed) } \\
\text { Major depression with suicidal risk diagnosis frequency: } \\
\text { 31.4\% (exposed) vs. 8.0\% (unexposed) } \\
\text { Generalized anxiety diagnosis frequency: } \\
\text { 14.3\% (exposed) vs. 18.0\% (unexposed) } \\
\text { No psychiatric disorder diagnosis frequency: } \\
36 \% \text { (exposed) vs. 64\% (unexposed) } \\
\text { Positive association between AChE activity \& psychiatric } \\
\text { disorders such as suicide risk: } \\
p=0.006\end{array}$ \\
\hline $\begin{array}{l}\text { Shrestha S et al. } \\
\text { January } 2019 \\
\text { [73] }\end{array}$ & $\begin{array}{l}\text { Subset of the Agricultural } \\
\text { Health Study (AHS) who } \\
\text { completed the third AHS follow- } \\
\text { up and met all study inclusion } \\
\text { criteria: } \\
11,232 \text { pesticide applicators } \\
\text { from North Carolina and lowa }\end{array}$ & $\begin{array}{l}\text { Self-reported experience of a high } \\
\text { pesticide exposure event (HPEE) }\end{array}$ & $\begin{array}{l}\text { Self-reported olfactory } \\
\text { impairment }\end{array}$ & $\begin{array}{l}\text { Olfactory impairment and: } \\
\text { History of HPEE reported at enrollment: } \\
\mathrm{OR}=1.49, \mathrm{Cl} 1.28-1.73 \\
\text { HPEE involving the respiratory or digestive track: } \\
\mathrm{OR}=1.53, \mathrm{Cl} 1.22-1.92 \\
\text { HPEE involving dermal contact: } \\
\mathrm{OR}=1.47, \mathrm{Cl} 1.22-1.78\end{array}$ \\
\hline \multicolumn{5}{|c|}{ Respiratory Effects } \\
\hline $\begin{array}{l}\text { Buralli RJ et al. } \\
\text { June } 2018 \text { [79] }\end{array}$ & $\begin{array}{l}48 \text { farm workers in tomato } \\
\text { cultivation in Brazil and } 34 \\
\text { relatives residing in the same } \\
\text { area who also may have helped } \\
\text { in agricultural activities }\end{array}$ & $\begin{array}{l}\text { Rural workers and relatives were } \\
\text { considered exposed to pesticides, } \\
\text { specifically } 49 \text { pesticides from } 31 \\
\text { chemical groups based on self- } \\
\text { reported use } \\
\text { Crop season (active work in tomato } \\
\text { cultivation) and off-season (not } \\
\text { working in agriculture) were } \\
\text { compared, blood acetylcholinesterase } \\
\text { (AChE) and butyrylcholinesterase } \\
\text { (BChE) activity was also measured }\end{array}$ & $\begin{array}{l}\text { Self-reported respiratory } \\
\text { symptoms based on the European } \\
\text { Community Respiratory Health } \\
\text { Survey (ECRHS) and spirometry } \\
\text { testing }\end{array}$ & $\begin{array}{l}\text { Crop season and: } \\
\text { Wheeze or chest tightness: } \\
\text { OR=2.25, Cl } 0.63-10 \\
\text { Wheeze with breathlessness: } \\
\text { OR=0.67, Cl } 0.06-5.82 \\
\text { Wheeze without cold: } \\
\text { OR=1.5, Cl } 0.17-17.96 \\
\text { Waking with chest tightness: } \\
\text { OR=6, Cl } 0.73-275.99 \\
\text { Waking with cough: } \\
\text { OR=5.5, Cl } 1.20-51.07 \\
\text { Nasal allergies and hay fever: } \\
\text { OR=2.4, Cl } 0.79-8.70\end{array}$ \\
\hline
\end{tabular}


This is an author-produced, peer-reviewed version of this article. The final, definitive version of this document can be found online at Synthetic Chemicals and Health, published by Springer. Copyright restrictions may apply. doi: 10.1007/s40572-020-00266-5

\begin{tabular}{|c|c|c|c|c|}
\hline \multicolumn{5}{|c|}{ Metabolic Effects } \\
\hline $\begin{array}{l}\text { Park S et al. } \\
\text { January } 2019 \\
{[83]}\end{array}$ & $\begin{array}{l}\text { Korea Farmers Cohort Study: } \\
2,559 \text { farmers and farm } \\
\text { managers from rural areas of } \\
\text { Wonju and Pyeongchang, } \\
\text { Gangwon-do, Korea, recruited } \\
\text { from } 2005 \text { - } 2008\end{array}$ & $\begin{array}{l}\text { Intensity level [(mixing } \\
\text { status+application method +repair } \\
\text { status) } \times \text { Personal Protective } \\
\text { Equipment] and Cumulative Exposure } \\
\text { Index (CEI) [intensity level } \times \text { duration } \\
\text { (number of years) } \times \text { frequency } \\
\text { (average days per year)], from } \\
\text { questionnaires on occupation as a } \\
\text { farmer, mixing or applying pesticides, } \\
\text { and specifics of pesticide use }\end{array}$ & $\begin{array}{l}\text { Prevalence of diabetes defined by } \\
\text { fasting plasma glucose } \geq \\
126 \mathrm{mg} / \mathrm{dL} \text {, or } 2 \text {-hour plasma } \\
\text { glucose } \geq 200 \mathrm{mg} / \mathrm{dL} \text { during oral } \\
\text { glucose tolerance test, or HbA1c } \\
\geq 6.5 \% \text {, or reported current use of } \\
\text { insulin or antidiabetic medication }\end{array}$ & $\begin{array}{l}\text { Diabetes and: } \\
\text { Ever pesticide use: } \\
\mathrm{OR}=1.58, \mathrm{Cl} 1.13-2.21 \\
\geq 20 \text { years of pesticide use: } \\
\mathrm{OR}=1.51, \mathrm{Cl} 1.07-2.14 \\
\geq 10 \text { days of pesticide use per year: } \\
\mathrm{OR}=1.53, \mathrm{Cl} 1.09-2.15 \\
\text { Pesticide exposure at lower intensity level: } \\
\mathrm{OR}=1.55, \mathrm{Cl} 1.07-2.24 \\
\mathrm{Pesticide} \text { exposure at higher intensity level: } \\
\mathrm{OR}=1.53, \mathrm{Cl} 1.06-2.22 \\
\mathrm{Higher} \mathrm{CEI}: \\
\mathrm{OR}=1.54, \mathrm{Cl} 1.03-2.30\end{array}$ \\
\hline $\begin{array}{l}\text { Kongtip P et al. } \\
\text { November } 2018 \\
\text { [84] }\end{array}$ & $\begin{array}{l}243 \text { conventional farmers and } \\
235 \text { organic farmers in Thailand }\end{array}$ & $\begin{array}{l}\text { Work as a conventional farmer was } \\
\text { considered exposed, work as an } \\
\text { organic farmer was considered non- } \\
\text { exposed }\end{array}$ & $\begin{array}{l}\text { Body mass index (BMI), waist } \\
\text { circumference, percent body fat, } \\
\text { blood pressure, metabolic } \\
\text { syndrome, and blood sample } \\
\text { analysis of serum glucose, } \\
\text { triglycerides (TGs), total } \\
\text { cholesterol (TC), high-density } \\
\text { lipoprotein (HDL), and low-density } \\
\text { lipoprotein (LDL) }\end{array}$ & $\begin{array}{l}\text { Conventional farm work to organic farm work: } \\
\text { BMI: } \\
\text { RR=1.83, Cl } 1.20-2.78 \\
\text { Waist circumference: } \\
\text { RR=1.69, Cl } 1.13-2.51 \\
\text { Percent body fat: } \\
\text { RR=1.31, Cl } 1.05-1.64 \\
\text { TGs: } \\
\text { RR=1.51, Cl } 1.01-2.27 \\
\text { TC: } \\
\text { RR=2.20, Cl } 1.69-2.86 \\
\text { LDL: } \\
\text { RR }=1.34, \mathrm{Cl} 1.14-1.57 \\
\text { HDL: } \\
\text { RR }=0.83, \mathrm{Cl} 0.37-0.95\end{array}$ \\
\hline
\end{tabular}


This is an author-produced, peer-reviewed version of this article. The final, definitive version of this document can be found online at Synthetic Chemicals and Health, published by Springer. Copyright restrictions may apply. doi: 10.1007/s40572-020-00266-5

\begin{tabular}{|c|c|c|c|c|}
\hline \multicolumn{5}{|c|}{ Thyroid Effects } \\
\hline $\begin{array}{l}\text { Shrestha S et al. } \\
\text { Sept } 2018 \text { [89] }\end{array}$ & $\begin{array}{l}\text { Subset of the Agricultural } \\
\text { Health Study (AHS) who } \\
\text { completed at least one follow- } \\
\text { up survey between } 1999 \text { and } \\
\text { 2016: } \\
\text { 38,698 pesticide applicators } \\
\text { from North Carolina and lowa }\end{array}$ & $\begin{array}{l}\text { Ever/never use of pesticides and } \\
\text { intensity-weighted cumulative days of } \\
\text { pesticide use based on self- } \\
\text { administered questionnaires on farm } \\
\text { life \& agricultural practices, types of } \\
\text { crops \& livestock, and pesticide } \\
\text { use/use of }>50 \text { individual pesticide } \\
\text { active ingredients }\end{array}$ & Self-reported hypothyroidism & $\begin{array}{l}\text { Hypothyroidism and: } \\
\text { Ever use of chlordane: } \\
\mathrm{HR}=1.21, \mathrm{Cl} 1.04-1.41 \\
\text { Ever use of diazinon: } \\
\mathrm{HR}=1.27, \mathrm{Cl} 1.10-1.48 \\
\text { Ever use of dichlorvos: } \\
\mathrm{HR}=1.42, \mathrm{Cl} 1.17-1.72 \\
\text { Ever use of malathion: } \\
\mathrm{HR}=1.23, \mathrm{Cl} 1.04-1.46 \\
\text { Ever use of dicamba: } \\
\mathrm{HR}=1.27, \mathrm{Cl} 1.08-1.50 \\
\text { Ever use of glyphosate: } \\
\mathrm{HR}=1.28, \mathrm{Cl} 1.07-1.52 \\
\text { Ever use of } 2,4-\mathrm{D}: \\
\mathrm{HR}=1.30, \mathrm{Cl} 1.07-1.58\end{array}$ \\
\hline $\begin{array}{l}\text { Bernieri T et al. } \\
\text { March } 2019 \text { [91] }\end{array}$ & $\begin{array}{l}46 \text { soybean growers and } 27 \\
\text { individuals not exposed to } \\
\text { pesticides an urban area of } \\
\text { Brazil }\end{array}$ & $\begin{array}{l}\text { Employment as a soybean grower was } \\
\text { considered exposed to pesticides, } \\
\text { blood butyrylcholinesterase (BChE) } \\
\text { activity was also measured }\end{array}$ & $\begin{array}{l}\text { Serum levels of free thyroxin } \\
\text { (FT4), total triiodothyronine (TT3) } \\
\text { and thyroid-stimulating hormone } \\
\text { (TSH) }\end{array}$ & $\begin{array}{l}\text { Activity of BChE (U/L): } \\
\text { 7969.8 } \pm 1582.3 \text { (exposed) vs. } 9140.2 \pm 2032.3 \text { (unexposed) } \\
\text { U/L, } p=0.006 \\
\text { TT3 (ng/dL): } \\
139.0 \pm 28.6 \text { (exposed) vs. } 104.5 \pm 20.0 \text { (unexposed) } \mathrm{ng} / \mathrm{dL} \text {, } \\
p=<0.001 \\
\text { FT4 (ng/dL): } \\
0.78 \pm 0.15 \text { (exposed) vs. } 0.66 \pm 0.09 \text { (unexposed) } \mathrm{ng} / \mathrm{dL} \text {, } \\
\mathrm{p}=<0.001 \\
\text { TSH ( } \mu \mathrm{UI} / \mathrm{mL} \text { ): } \\
2.15 \pm 1.09 \text { (exposed) vs. } 2.91 \pm 1.35 \text { (unexposed) } \mu \mathrm{Ul} / \mathrm{mL} \text {, } \\
p=0.007\end{array}$ \\
\hline
\end{tabular}

